\title{
Petrologia e geocronologia do Batólito Rio Jacaré, Domínio Poço Redondo, Sistema Orogênico Sergipano, NE do Brasil
}

Petrology and Geochronology of the Rio Jacaré Batholith, Poço Redondo Domain, Sergipano Orogenic System, NE of Brazil

\author{
Carlos Santana Sousa ${ }^{1,2}$ (1), Hiakan Santos Soares ${ }^{1,2}$ (1), \\ Maria de Lourdes da Silva Rosa ${ }^{1,2}$ (1) , Herbet Conceição ${ }^{1,2}$ (1) \\ ${ }^{1}$ Universidade Federal de Sergipe - UFS, Programa de Pós-Graduação em Geociências e Análise de Bacias - PGAB, \\ Avenida Marechal Rondon, $\mathrm{s} / \mathrm{n}^{\circ}$, Jardim Rosa Elze, Cidade Universitária Professor José Aloísio de Campos, CEP 49100-000, \\ São Cristóvão, SE, BR (karlcss@hotmail.com; hiakan1@hotmail.com; Irosa@ufs.br; herbet@ufs.br) \\ ${ }^{2}$ Universidade Federal de Sergipe - UFS, Laboratório de Petrologia Aplicada à \\ Pesquisa Mineral - LAPA, Galpão das Geociências, São Cristóvão, SE, BR
}

Recebido em 09 de dezembro de 2018; aceito em 17 de abril de 2019

\begin{abstract}
Resumo
O Batólito Rio Jacaré (BRJ) (167 km²), localizado no sul do Domínio Poço Redondo (DPR), Sistema Orogênico Sergipano (SOS), é um corpo intrusivo com frequente foliação magmática e onde não se observa deformação no estado sólido. As rochas do BRJ têm composições monzogranítica, granodiorítica e quartzo monzonítica, cor cinza, granulação média a grossa e texturas inequigranular e porfirítica. Enclaves máficos microgranulares (EMM) são abundantes, têm composições diorítica e granodiorítica, e preservam feições de mingling e mixing. Os EMM apresentam cor cinza-escura, tamanhos de até $2 \mathrm{~m}$ e granulação fina. As rochas do BRJ e os enclaves têm mineralogia similar. Os minerais máficos são biotita, hornblenda e óxidos de ferro-titânio. Os plagioclásios (andesina e oligoclásio) exibem zoneamentos composicionais múltiplos, dominantemente normais, indicando existência de fracionamento magmático. $\mathrm{O}$ feldspato alcalino (ortoclásio e microclina) tem composição de $\mathrm{Or}_{75-98}-\mathrm{Ab}_{25-2}$. A biotita $(0,3<\mathrm{Fe} /(\mathrm{Fe}+\mathrm{Mg})<0,6)$ é magmática e apresenta-se reequilibrada. A Mg-hornblenda e edenita magmáticas cristalizaram sob condições de alta $\mathrm{fO}_{2}$, a profundidade máxima de $25 \mathrm{~km}$ e temperatura de $826,3^{\circ} \mathrm{C}$. Os dados geoquímicos indicam que as rochas do BRJ são magnesianas, metaluminosas e exibem afinidades com as séries calcioalcalina de alto $\mathrm{K}$ a álcali-cálcica, e os enclaves são shoshoníticos. As razões $[\mathrm{La} / \mathrm{Yb}]_{\mathrm{N}}(13-133)$ e as anomalias negativas de Eu evidenciam alto grau de fracionamento. O BRJ é ediacarano e possui idade de cristalização U-Pb $\mathrm{S}_{\text {SHRIMP }}$ de $617 \pm 4 \mathrm{Ma}$. Os baixos conteúdos de $\mathrm{Ta}$, $\mathrm{Nb}$, Ti e $\mathrm{P}$, e moderados de $\mathrm{Y}, \mathrm{Nb}$ e Rb dessas rochas indicam magmas formados em ambiente orogênico pós-colisional.
\end{abstract}

Palavras-chave: Granitos; Enclaves máficos microgranulares; Pós-colisional.

\begin{abstract}
The Rio Jacaré Batholith (RJB, $167 \mathrm{~km}^{2}$ ), southern part of the Poço Redondo Domain, Sergipano Orogenic System, is an intrusive body with frequent magmatic foliation and no visible deformations. Its rocks have monzogranitic, granodioritic and monzonite quartz compositions, gray color, medium to gross granulation with inequigranular and porphyritic textures. Microgranular mafic enclaves are abundant, with dioritic and granodioritic compositions, and preserve mingling and mixing features. They have dark gray color, sizes up to $2 \mathrm{~m}$ and fine grain size. RJB rocks and their enclaves have similar mineralogy. The mafic minerals are biotite, hornblende and iron-titanium oxides. The plagioclases (andesine and oligoclase) present compositional zoning, dominantly normal, suggesting the existence of magmatic fractionation. The alkaline feldspar (orthoclase and microcline) has a composition of $\mathrm{Or}_{75-98}-\mathrm{Ab}_{25-2}$. The biotite $(0.3<\mathrm{Fe} /(\mathrm{Fe}+\mathrm{Mg})<0.6)$ is magmatic and equilibrated. The magmatic $\mathrm{Mg}$-hornblende and edenite crystallized under conditions of high $\mathrm{fO}_{2}$, at a maximum depth of $25 \mathrm{~km}$ and temperature of approximately $826.3^{\circ} \mathrm{C}$. Geochemical data show that RJB rocks are magnesian, metaluminous and belong to the calc-alkaline of high $\mathrm{K}$ and alkali-calcic series, and that their enclaves are shoshonitic. The $[\mathrm{La} / \mathrm{Yb}]_{\mathrm{N}}(13-133)$ and negative Eu anomalies show a high fractionation degree. The RJB is Ediacaran with a U-Pb $b_{\text {SHRIMP }}$ age of $617 \pm 4 \mathrm{Ma}$. The low contents of Ta, $\mathrm{Nb}, \mathrm{Ti}$ and $\mathrm{P}$, and moderates of $\mathrm{Y}, \mathrm{Nb}$ and $\mathrm{Rb}$ of the rocks indicate magmas generated in orogenic post-collisional environment.
\end{abstract}

Keywords: Granites; Mafic microgranular enclaves; Post-collisional. 


\section{INTRODUÇÃO}

Batólitos são corpos ígneos com área superior a $100 \mathrm{~km}^{2}$ (Bates e Jackson, 1980). Em razão das suas dimensões, eles podem apresentar feições variáveis (por exemplo, composições química e mineralógica, estrutura, textura e presença ou ausência de enclaves.). Essas variações internas fazem com que os batólitos sejam corpos magmáticos complexos, sendo necessário reunir várias informações (e.g., geologia de campo, petrografia, química mineral e geoquímica clássica e isotópica) para que se possa compreender adequadamente a sua história evolucional.

Nos domínios Macururé, Marancó, Poço Redondo e Canindé, localizados na região norte do Sistema Orogênico Sergipano (SOS) (Conceição et al., 2016), na parte sul da Província Borborema (Almeida et al., 1977), ocorre um volumoso plutonismo neoproterozoico (Davison e Santos, 1989). Apesar de existirem trabalhos sobre granitos nesse orógeno (e.g., Santos e Souza, 1988; Gaston e Santos, 1988; McReath et al., 1998; Davison e Santos, 1989; Fujimori, 1989; Santos et al., 2001; Bueno et al., 2009; Oliveira et al., 2015; Conceição et al., 2016), há necessidade de estudos de detalhe e que foquem na petrogênese, tendo como base dados petrográfico, mineraloquímico, geoquímico e geocronológico.

Este texto apresenta e discute dados de campo, petrográfico, mineraloquímico, geoquímico e geocronológico do Batólito Rio Jacaré (BRJ), que é o segundo maior corpo intrusivo do Domínio Poço Redondo (DPR) no SOS, inferindo-se sobre a natureza do magma gerador dessas rochas, a sua idade e as condições de cristalização.

\section{CONTEXTO REGIONAL}

O BRJ, objeto deste estudo, localiza-se no DPR, que corresponde a um dos sete domínios geológicos do SOS (Davison e Santos, 1989; Silva Filho e Torres, 2002). O DPR representa, segundo Santos et al. (2001), a exposição do nível crustal mais profundo entre os domínios geológicos do SOS. Ele é formado pelo Complexo Migmatítico Poço Redondo (Santos e Souza, 1988) e por granitos neoproterozoicos (Carvalho, 2005). O DPR é limitado a norte, com o Domínio Canindé, pela Zona de Cisalhamento Macururé e a sul, com o Domínio Marancó, pela Zona de Cisalhamento Poço Redondo (Figura 1).

O Complexo Migmatítico Poço Redondo constitui uma faixa contínua, com $50 \mathrm{~km}$ de comprimento, orientada na direção NW-SE, e é considerado por Santos et al. (2001) como embasamento dos granitos desse domínio. O paleossoma do migmatito apresenta estruturas schlieren e nebulítica e corresponde a gnaisse tonalítico e granodiorítico, ocasionalmente com biotita e granada. O neossoma é constituído de produtos de fusão quartzo-feldspáticos. As idades $\mathrm{U}-\mathrm{Pb}_{\text {SHRIMP }}$ em zircão do paleossoma variam de 980 a $960 \mathrm{Ma}$, e foram interpretadas como da formação do protólito na Orogênese Cariris Velhos (Carvalho, 2005).

Teixeira et al. (2014) identificam no DPR a presença de seis suítes intrusivas graníticas: Serra Negra, Sítios Novos, Serra do Catu, Coronel João Sá, Queimada Grande e Glória-Xingó 2.

A Suíte Intrusiva Serra Negra (Figura 1) é constituída de gnaisse granítico e granito porfirítico com assinatura geoquímica de granito do tipo A (Carvalho, 2005; Lima et al., 2017). Esses granitos ocorrem como faixas orientadas NW-SE na região sudeste no DPR (Santos e Souza, 1988). Lima et al. (2017) obtiveram idade $\mathrm{U}_{-} \mathrm{Pb}_{\text {SHRIMP }}$ concordante em zircão de $933 \pm 7 \mathrm{Ma}$. A presença desse magmatismo anorogênico no DPR indica a existência de período distensivo nesse setor da Província Borborema durante o evento Cariris Velhos (Oliveira et al., 2010).

A Suíte Intrusiva Sítios Novos (Figura 1) tem como seu maior plúton o batólito homônimo, com área de $110 \mathrm{~km}^{2}$ (Pinho Neto et al., 2017), que tem idade de cristalização $\mathrm{U}-\mathrm{Pb}_{\text {SHRIMP }}$ de $631 \pm 4 \mathrm{Ma}$ (Oliveira et al., 2015). Nos corpos dessa suíte, têm-se composições de granito e granodiorito, os quais são inequigranulares, exibem granulação média, não apresentam orientação e têm raros enclaves (Carvalho, 2005; Oliveira et al., 2015; Pinho Neto et al., 2017). Os dados disponibilizados por esses autores permitiram identificar granitos fortemente evoluídos da série calcioalcalina de alto $\mathrm{K}$, os quais apresentam assinaturas geoquímicas para o magma-fonte como sendo de arco-vulcânico e sin-colisional.

A Suíte Intrusiva Serra do Catu tem como representante o Batólito Curituba $\left(111 \mathrm{~km}^{2}\right)$, que se localiza a oeste do DPR, é orientado NE-SW e trunca a orientação regional NW-SE presente nesse domínio (Gentil, 2013). Esse batólito tem idade de cristalização U-Pb SHRIMP $_{\text {de }} 624 \pm 16 \mathrm{Ma}$ (Lima, 2016) e é constituído de monzogranito, sienogranito, monzonito, sienito e por enclaves máficos (Gentil, 2013; Lima, 2016). Os dados geoquímicos indicam afinidade shoshonítica e assinatura de arco vulcânico (Gentil, 2013; Lima, 2016).

A Suíte Intrusiva Coronel João Sá nessa região tem como seu maior representante o Batólito Poço Redondo, com $190 \mathrm{~km}^{2}$ (Figura 1). Esse batólito é orientado na direção NW-SE e tem idade de cristalização U-Pb $b_{\text {ShrimP }}$ de $623 \pm 7 \mathrm{Ma}$ (Oliveira et al., 2015). Esse plutonismo é constituído essencialmente de monzogranito ferroso sem evidências importantes de deformação (Teixeira et al., 2014).

A Suíte Intrusiva Queimada Grande no DPR é representada pelo BRJ $\left(167 \mathrm{~km}^{2}\right)$ e por três stocks $\left(<14 \mathrm{~km}^{2}\right.$, Figura 1B). As rochas dessa suíte têm composições de monzonito, monzogranito e granodiorito, apresentam textura porfirítica e têm abundância de enclaves máficos microgranulares (EMM), os quais exibem feições de mingling (Santos e Souza, 1988; Brito, 1996; Teixeira et al., 2014; Sousa et al., 
2017). Os dados geoquímicos disponíveis para esse plutonismo (Brito, 1996; Oliveira et al., 2015; Sousa et al., 2017) indicam afinidades com a série calcioalcalina de alto $\mathrm{K}$.

A Suíte Intrusiva Glória-Xingó 2 (Figura 1) ocorre no DPR como stocks e diques cortando as demais rochas da região (Teixeira et al., 2014). Segundo Guimarães e Silva Filho (1995), esses stocks são formados de granitos hololeucocráticos com duas micas e correspondem a produtos da fusão parcial dos migmatitos. Gouveia (2016), estudando um desses stocks, identificou caráter peraluminoso das rochas e com assinatura geoquímica de arco vulcânico.

\section{GEOLOGIA LOCAL}

O BRJ tem forma alongada na direção NW-SE (Figura 1) e aflora como abundantes lajedos. O BRJ é intrusivo no Complexo Migmatítico Poço Redondo, no Batólito Sítios Novos e em rochas da Suíte Intrusiva Serra Negra. Os seus contatos com o embasamento geralmente são capeados por solo, mas ocasionalmente se observam contatos bem definidos e reentrantes com os migmatitos. Foram identificadas duas fácies petrográficas no BRJ: porfirítica e inequigranular. As rochas dessas fácies são ricas em EMM e
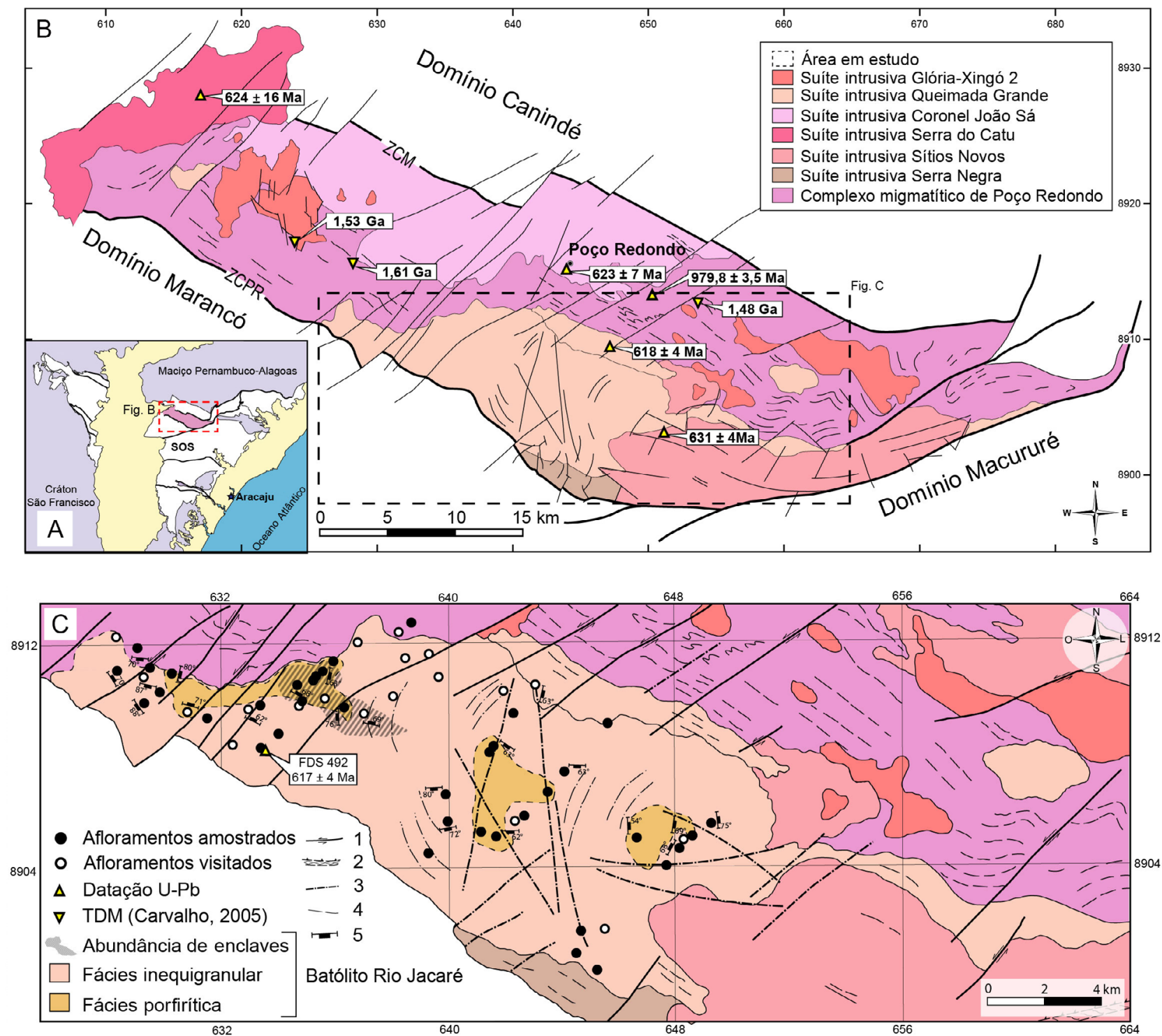

ZCM: Zona de Cisalhamento Macururé; ZCPR: Zona de Cisalhamento Poço Redondo; SOS: Sistema Orogênico Sergipano; TDM: Idade modelo; 1: falha; 2: zona de cisalhamento; 3: fratura; 4: lineamentos; 5: foliação magmática.

Figura 1. (A) Mapa de situação do Sistema Orogênico Sergipano, após Pinho Neto et al. (2017); (B) mapa geológico simplificado do Domínio Poço Redondo (Pinho Neto et al., 2017); (C) esquema geológico do Batólito Rio Jacaré, modificado de Santos e Souza (1988). 
localmente encontram-se diques pegmatíticos e aplíticos, correlacionados em razão da presença da muscovita à Suíte Intrusiva Glória-Xingó 2.

A Fácies Inequigranular (FI) é a predominante no BRJ (Figuras 1 e 2A). Ela é constituída de rochas de cor cinza, com textura inequigranular média a fina e com foliação magmática dada pela orientação dos EMM e dos minerais máficos. Aglomerados de biotita, hornblenda, titanita e minerais opacos ( $\pm 1 \mathrm{~cm}$ de diâmetro) são ocasionalmente observados.

A Fácies Porfirítica (FP) ocorre no BRJ em três regiões: leste, central e a oeste (Figura 1). As rochas dessa fácies são de cor cinza, porfiríticas com matriz de granulação média e, por vezes, exibem orientação dos fenocristais e dos EMM. Os fenocristais são de feldspato alcalino euédricos, ricos em inclusões e com tamanhos em torno de $1 \mathrm{~cm}$. Na região leste, porém, os fenocristais apresentam tamanhos ainda maiores, entre 1 e $5 \mathrm{~cm}$ (Figura 2B), e localmente são muito abundantes, existindo acumulação de fenocristais formada pelo fluxo magmático.

Os EMM no BRJ têm tamanhos que variam de $5 \mathrm{~cm}$ a $2 \mathrm{~m}$ e possuem formas arredondadas, em gotas e elípticas. As bordas desses enclaves são geralmente bem definidas, por vezes apresentando feições de reação com presença de biotita. Os contatos são arredondados, cúspides (Figura 2C) e eventualmente ameboides. Notam-se xenocristais de feldspato alcalino nesses enclaves. É comum a presença de enclaves múltiplos (Figura 2D), alguns com cor mais clara e outros com cor mais escura, e essa variação é interpretada como resultado de diferentes intensidades da mistura entre magmas. Observa-se que, na porção noroeste do batólito, os EMM são mais abundantes (Figura 2E). Nesse local, eles possuem os maiores tamanhos e é comum a presença de diques sin-plutônicos (Figura 2F). Nota-se também a diminuição nos tamanhos e na quantidade dos enclaves da região oeste para leste no $\mathrm{BRJ}$ e, no mesmo sentido, há aumento no conteúdo de aglomerados máficos $( \pm 0,3 \mathrm{~cm})$.

\section{PETROGRAFIA}

A nomenclatura das rochas neste estudo seguiu as recomendações da IUGS (Le Maître et al., 1989), e os dados modais, obtidos a partir de estimativa visual em 35 campos por lâmina delgada, encontram-se na Tabela 1. As rochas dominantes nesse batólito são monzogranito, granodiorito e quartzo monzonito (Figura 3 ). Os enclaves têm composições de granodiorito, quartzo monzodiorito, quartzo diorito, diorito e tonalito (Figura 3).

As rochas da FI possuem composições granodiorítica, monzogranítica e quartzo monzonítica (Figura 3). Os cristais de microclina pertítica, plagioclásio e, mais raramente, quartzo têm geralmente tamanhos um pouco maiores que os demais minerais da rocha, alcançando até $5 \mathrm{~mm}$, enquanto os outros minerais são menores que $1 \mathrm{~mm}$. Ocasionalmente, ocorrem aglomerados de cristais de quartzo e de minerais máficos (Figura 4A). O plagioclásio é subédrico a anédrico, tem geminação albita e albita-Carlsbad e apresenta zoneamentos composicionais. Essas zonas são múltiplas, concêntricas e paralelas às faces, além de se observar a presença de zonas de inclusão com minerais opacos, biotita e hornblenda (Figuras 4B e 4C). As texturas antipertítica e synneusis são esporádicas nesses cristais. Zoneamentos composicionais também são observados na microclina e na hornblenda. A hornblenda verde é restrita às regiões sul $\mathrm{e}$ oeste do batólito. Ela é subédrica e possui inclusões de apatita, titanita e minerais opacos. Quando está zonada apresenta inclusões vermiculares de quartzo. A biotita marrom é subédrica, casualmente tem textura blade e inclui cristais euédricos de apatita, zircão e cristais anédricos de minerais opacos (magnetita e ilmenita) e titanita. O quartzo é anédrico e apresenta extinção ondulante. A titanita marrom pode ser euédrica e anédrica. Os cristais primários de titanita são euédricos e possuem tamanhos maiores $(0,8 \mathrm{~mm})$ que os cristais secundários $(<0,2 \mathrm{~mm})$, que são anédricos e ocorrem nos planos de clivagem da biotita. O epídoto ocorre em duas formas distintas: como cristais euédricos a subédricos (magmáticos), com tamanhos maiores $(1,0 \mathrm{~mm})$, e como cristais anédricos, com tamanhos menores $(<0,2 \mathrm{~mm})$ e sempre em fraturas e zonas de saussuritização ou em fraturas em biotita. Raramente, observam-se cristais de epídoto com centro de allanita (Figura 4D). Os minerais opacos (magnetita e ilmenita) são anédricos e associados com a biotita, a hornblenda e, principalmente, a titanita. A alteração nessas rochas é fraca e expressa-se pela cloritização e saussuritização localizadas.

As rochas da FP correspondem a monzogranito e granodiorito (Figura 2) e os fenocristais perfazem até $44 \%$ do volume. Essa fácies apresenta a mesma mineralogia e texturas da FI descrita anteriormente. Destaca-se, porém, pela presença da textura porfirítica, com fenocristais de plagioclásio, microclina e mais raramente quartzo, que alcançam tamanhos de até $1,5 \mathrm{~cm}$. Os fenocristais, por vezes, encontram-se orientados pelo fluxo magmático.

Os enclaves possuem composição diorítica, quartzo diorítica, quartzo monzodiorítica, granodiorítica e tonalítica (Figura 3), apresentando granulação fina e textura porfirítica a inequigranular. Eles são constituídos de plagioclásio, microclina/ortoclásio, biotita, quartzo, hornblenda, titanita, epídoto, allanita, magnetita, ilmenita, apatita e zircão. Os fenocristais são de plagioclásio (Figura 4E) e quartzo. Os cristais de plagioclásio exibem zoneamentos composicionais nas bordas e nas zonas de inclusão com cristais de biotita, hornblenda e minerais opacos. A microclina é raramente pertítica e é anédrica. Nos tonalitos, observa-se a ocorrência de ortoclásio. A biotita e a hornblenda são euédricas a subédricas e frequentemente participam dos aglomerados 

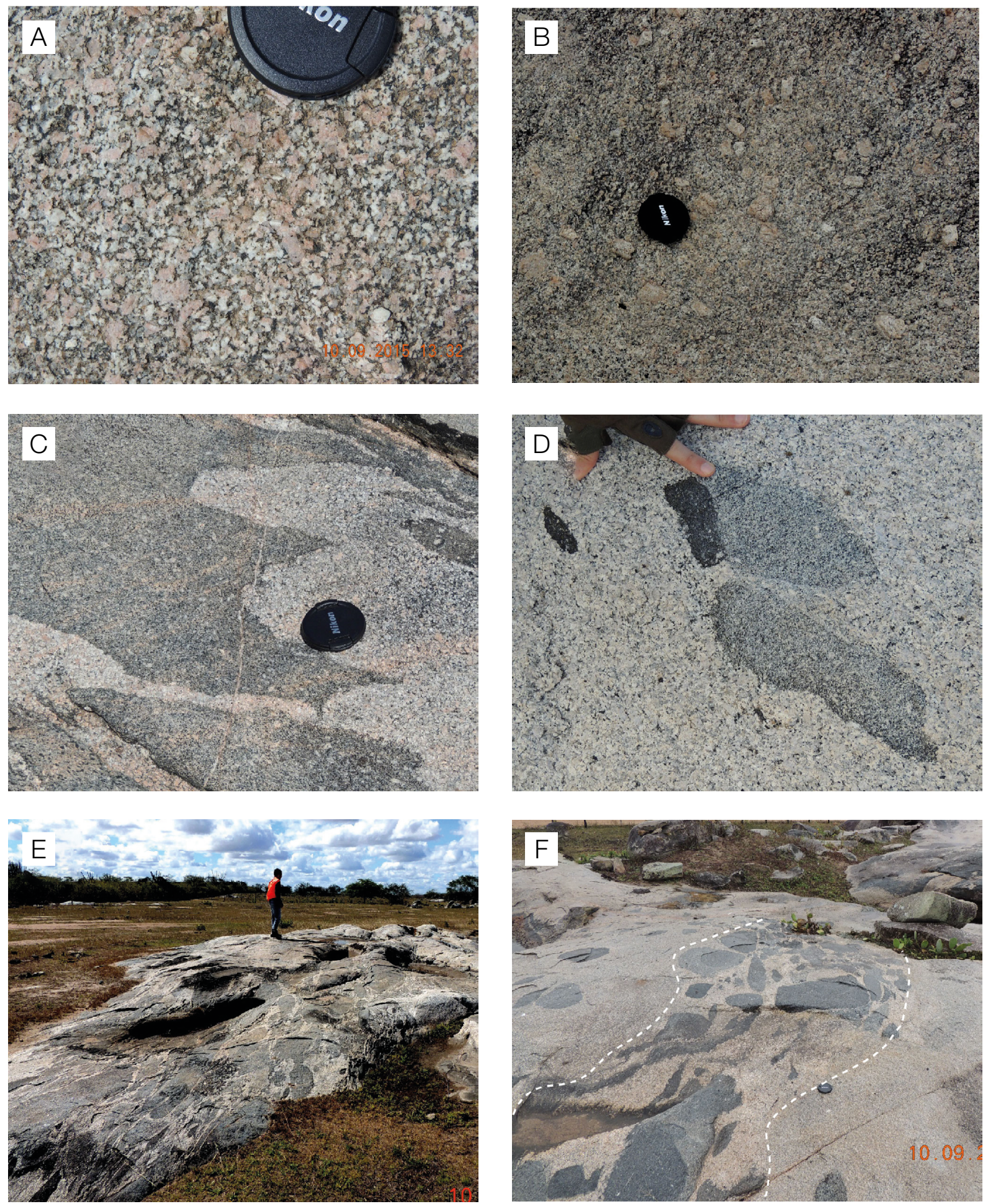

Figura 2. Feições de campo do Batólito Rio Jacaré. (A) Aspecto geral da Fácies Inequigranular do Batólito Rio Jacaré. Cristais róseos (feldspato alcalino), cristais brancos (plagioclásio) e cristais pretos (hornblenda, biotita e minerais opacos); (B) aspecto típico da Fácies Porfirítica no Batólito Rio Jacaré. Observa-se a presença de fenocristais de feldspato alcalino com tamanhos em torno de $2 \mathrm{~cm}$; (C) enclaves máficos microgranulares com contatos cúspides com o monzogranito hospedeiro; (D) enclaves múltiplos no Batólito Rio Jacaré. Observam-se enclaves com cor diferente em contato, além da presença de xenocristais de feldspato alcalino; (E) região rica em enclaves máficos microgranulares na porção oeste do Batólito Rio Jacaré; (F) dique sin-plutônico na região oeste do Batólito Rio Jacaré, e enclaves máficos microgranulares ligeiramente alongados e com tamanhos variáveis. 
Tabela 1. Análise modal das rochas do Batólito Rio Jacaré.

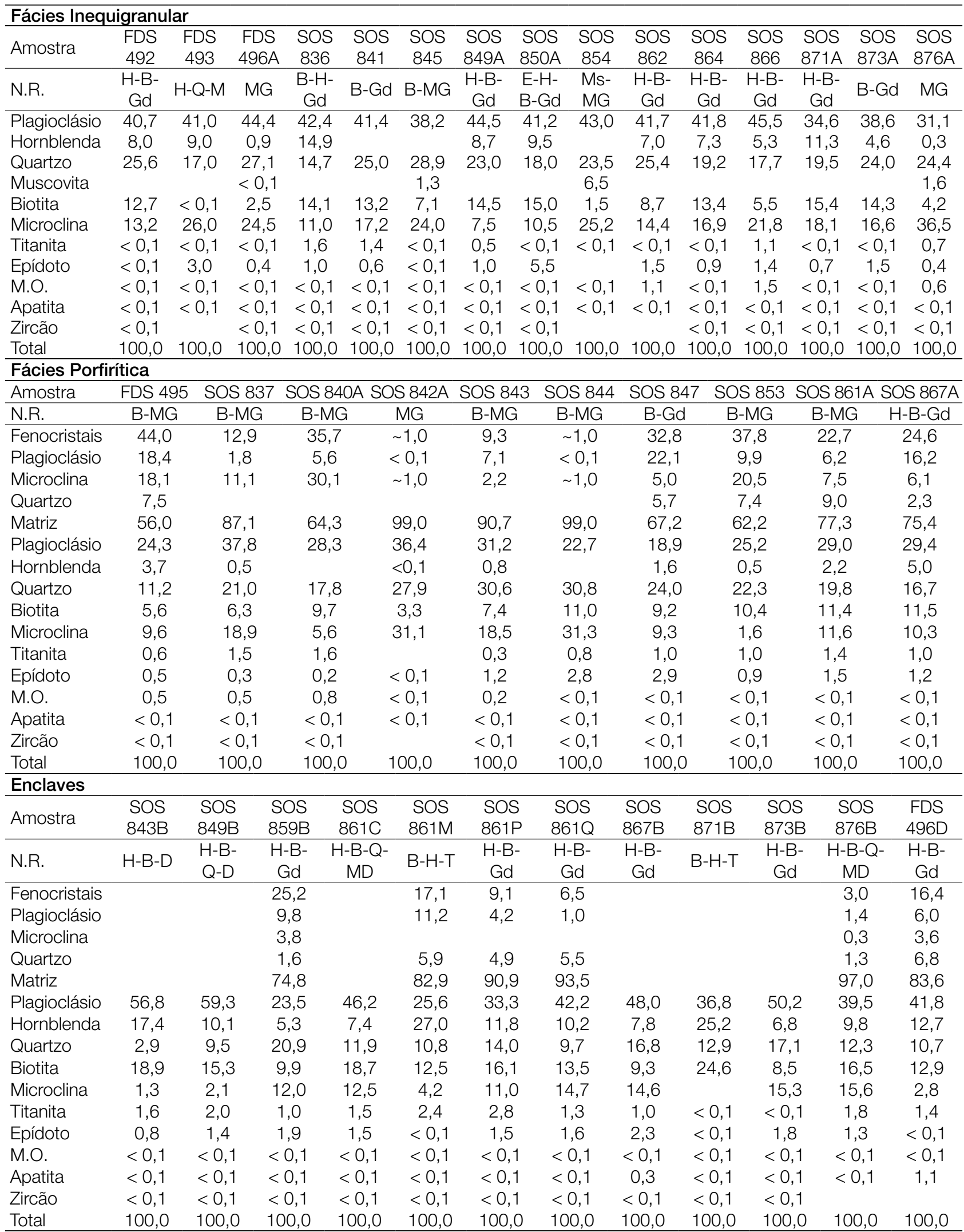

N.R: nome da rocha; H: hornblenda; B: biotita; Gd: granodiorito; Q: quartzo; M: monzonito; MG: monzogranito; E: epídoto; Ms: muscovita; D: diorito; MD: monzodiorito; T: tonalito; M.O.: minerais opacos. 
de minerais máficos associados a epídoto primário e apatita acicular (Figura 4F).

\section{QUÍMICA MINERAL}

Os dados químicos pontuais dos cristais de feldspatos, hornblenda, biotita e epídoto foram determinados com o espectrômetro de energia dispersiva (EDS), modelo X-Act da marca Oxford Instruments. Esse espectrômetro está instalado em um microscópio eletrônico de varredura (MEV), marca Tescan, modelo Vega LMU3, do Condomínio Laboratorial de Multiusuários das Geociências da Universidade Federal de Sergipe (CLGeo-UFS). As condições analíticas utilizadas neste estudo foram tensão de $20 \mathrm{kV}$, corrente de $17 \mathrm{nA}$, diâmetro do feixe de elétrons de $0,4 \mu \mathrm{m}$ e tempo de contagem médio de 30 segundos. Para a obtenção dos dados de química mineral foi necessário metalizar as lâminas delgadas polidas com carbono, utilizando o metalizador da marca Quorum, modelo Q150R ES.

\section{Feldspatos}

Na Tabela 2, apresentam-se dados químicos e fórmulas estruturais de cristais representativos dos feldspatos. Neste estudo, foram obtidas 225 análises químicas pontuais desses minerais, distribuídas em 23 lâminas do BRJ.

A composição dos cristais de plagioclásio (Figura 5) da FP corresponde a oligoclásio $\left(\mathrm{An}_{11-23}\right)$, e da FI e enclaves ela varia de oligoclásio a andesina $\left(\mathrm{An}_{12-33}\right.$ e $\mathrm{An}_{13-34}$, respectivamente). A variação composicional pode ser observada ao se analisar perfis químicos nos cristais (Figura 6) que exibem

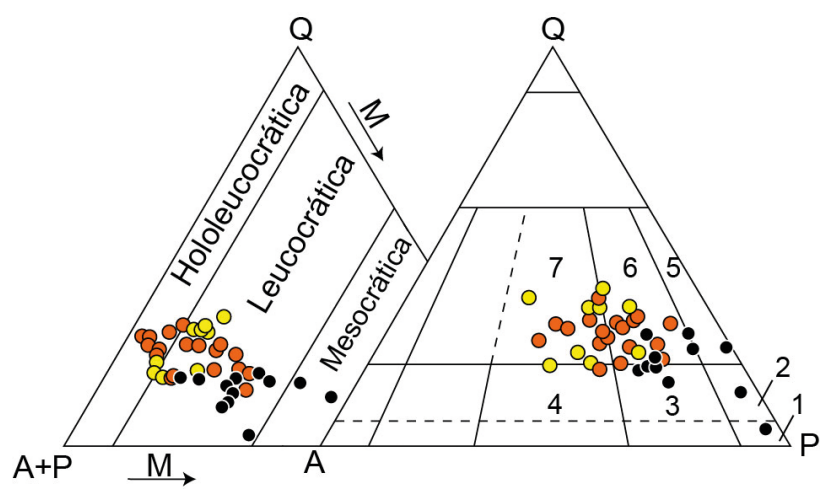

Q: quartzo; A: feldspato alcalino + albita com < $5 \%$ anortita; P: plagioclásio (anortita > $5 \%$ ); M: total de minerais máficos; 1: diorito; 2: quartzo diorito; 3: quartzo monzodiorito; 4: quartzo monzonito; 5: tonalito; 6: granodiorito; 7: monzogranito.

Figura 3. Classificação das rochas plutônicas estudadas nos diagramas QAP e Q(A + P)M de Streckeisen (1976): rochas do Batólito do Rio Jacaré da Fácies Inequigranular (círculo laranja), da Fácies Porfirítica (círculo amarelo) e os enclaves (círculo preto). zoneamentos normais, inversos e cíclicos. Nos cristais dos enclaves, constata-se a presença somente de zoneamentos normais, com um declínio importante no conteúdo de anortita do centro para a borda (e.g., de 34 a 24\%), enquanto nos cristais da FP e da FI ocorrem os zoneamentos oscilatórios, inversos e normais (Figura 6). Observou-se que nas rochas com hornblenda, o teor de anortita é sempre mais elevado (entre 20 e 33\%), enquanto nas rochas sem ou com pouca hornblenda, o conteúdo de anortita é menor que $23 \%$, o que sugere que, na região nordeste do batólito, as rochas sejam mais diferenciadas. $\mathrm{O}$ feldspato alcalino dos enclaves apresenta variação composicional de $\mathrm{Or}_{81-97}$; o da FI, de $\mathrm{Or}_{75-98}$; e o da FP, de $\mathrm{Or}_{89-96}$. As composições albíticas correspondem às exsoluções do feldspato alcalino.

\section{Biotita}

Os dados químicos dos cristais de biotita do BRJ (Tabela 3) mostram que as razões $\mathrm{Fe} /(\mathrm{Fe}+\mathrm{Mg})$ situam-se entre 0,6 e 0,3 e os conteúdos de $\mathrm{Si}$ alocam-se entre 5,5 e 6,0 átomos por fórmula unitária (apfu), e os cristais pertencentes à FP têm razões $\mathrm{Fe} /(\mathrm{Fe}+\mathrm{Mg})$ mais elevadas que os da FI. Os cristais dos enclaves apresentam variação da composição mais restrita, tendo razões $\mathrm{Fe} /(\mathrm{Fe}+\mathrm{Mg})$ entre 0,4 e 0,5 e os conteúdos de Si entre 5,5 e 5,85. Esses valores os alocam predominantemente no campo da biotita (Figura 7A).

As composições dos cristais de biotita estudados apresentam proporções de $\mathrm{TiO}_{2}$, $(\mathrm{FeO}+\mathrm{MnO})$ e $\mathrm{MgO}$ características de cristais primários reequilibrados (Figura 7B). Um decréscimo bem pronunciado do titânio é notado nos cristais de todas as rochas estudadas e reflete, provavelmente, o efeito do reequilíbrio (Figura 7B). Nas lâminas, esse reequilíbrio expressa-se pela presença de cristais anédricos de titanita e minerais opacos nas clivagens ou na periferia da biotita.

No BRJ, os cristais de biotita exibem conteúdos de $\mathrm{Al}_{2} \mathrm{O}_{3}, \mathrm{MgO}$ e $\mathrm{FeO}$ que, segundo Abdel-Rahman (1994), são característicos de cristais formados pela cristalização de magmas calcioalcalinos (Figura 7C). A gênese dos magmas (e.g., crustal, mantélico ou misto) tem sido inferida igualmente pela composição da biotita. Utilizando o diagrama proposto por Zhou (1986), aplicado para biotita de rochas subalcalinas, as composições dos cristais de biotita do BRJ alocam-se no campo relacionado à fonte mista (Figura 7D).

\section{Anfibólio}

Os cristais de anfibólio do BRJ (Tabela 4) exibem conteúdos $\mathrm{de}(\mathrm{Ca}+\mathrm{Na})_{\mathrm{B}}>1$ e $\mathrm{Na}_{\mathrm{B}}<0,5$, que correspondem ao grupo dos anfibólios cálcicos (Leake et al., 1997). Os cristais pertencentes à $\mathrm{FP}$ e à $\mathrm{FI}$ exibem composições de $\mathrm{Mg}$-hornblenda, apresentando tendência de aumento no conteúdo de $\mathrm{Mg}$ e 

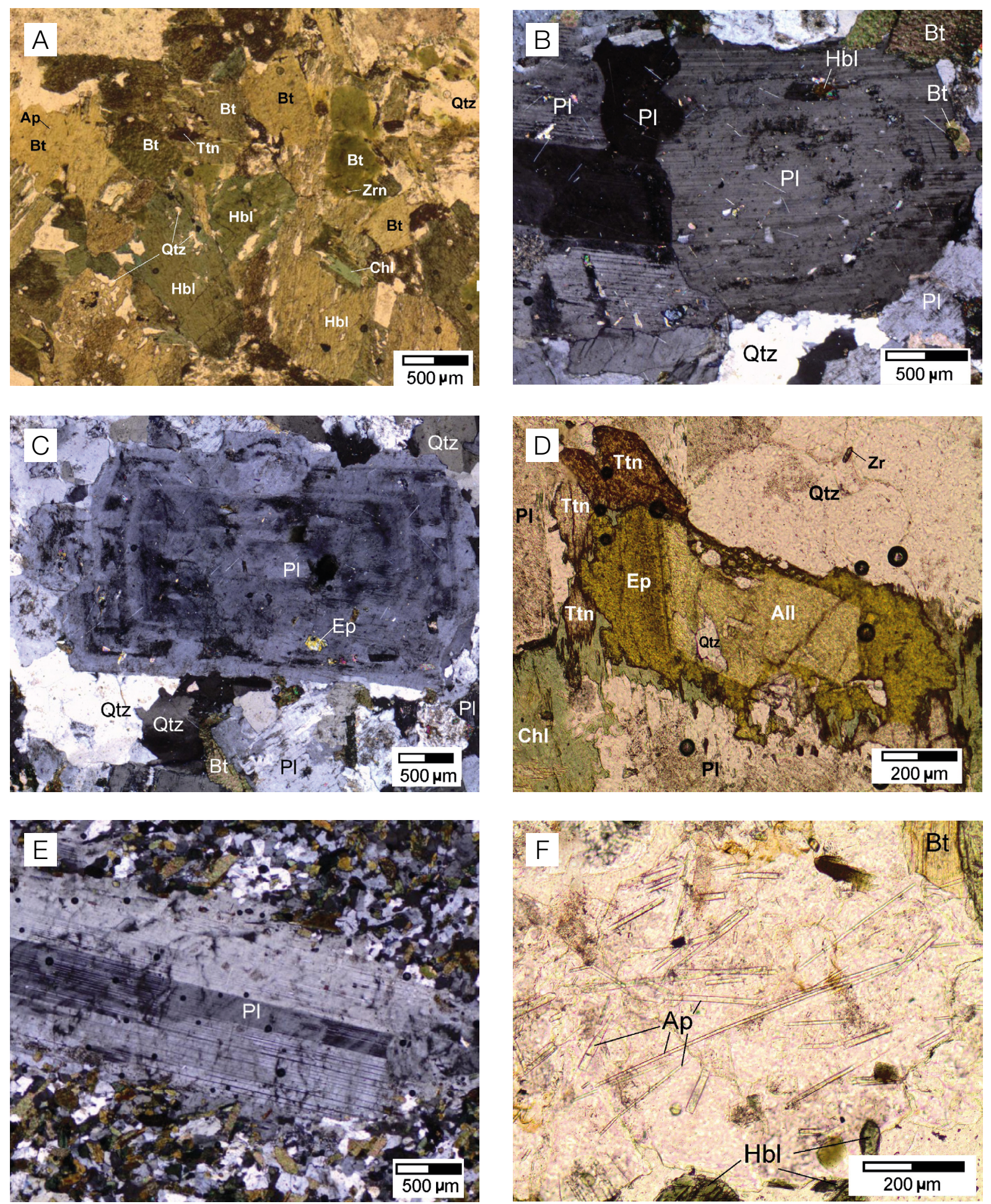

Qtz: Quartzo; PI: plagioclásio; Bt: biotita; Hbl: hornblenda; Ttn: titanita; Ep: epídoto; All: allanita; Ap: apatita; Zr: zircão; Chl: clorita.

Figura 4. Texturas em rochas do Batólito Rio Jacaré. (A) Aglomerado de minerais máficos em hornblenda biotita granodiorito da Fácies Inequigranular (luz plana); (B) plagioclásio exibindo zona de inclusão em biotita monzogranito porfirítico (polarizadores cruzados); (C) zoneamento composicional em fenocristal de plagioclásio em biotita monzogranito porfirítico (polarizadores cruzados); (D) epídoto com centro de allanita em hornblenda biotita monzogranito da Fácies Inequigranular (luz plana); (E) fenocristal de plagioclásio em enclaves máficos microgranulares (polarizadores cruzados); (F) cristais aciculares de apatita inclusos em plagioclásio de enclave máfico microgranular (polarizadores cruzados). 
$\mathrm{Si}$ (Figura 8A), podendo indicar o reequilíbrio com composições evoluindo para o campo da tremolita. Nos enclaves, os anfibólios possuem variação no conteúdo de Si similar ao observado nos granitos e variação na razão de $\mathrm{Mg} /(\mathrm{Mg}+$ $\left.\mathrm{Fe}^{2}\right)$ mais restrita $(0,6$ a 0,7$)$. A mineralogia presente nessas rochas com Mg-hornblenda, epídoto, plagioclásio, feldspato alcalino, minerais opacos (magnetita e ilmenita), titanita e quartzo permite utilizar o alumínio total da hornblenda como geobarômetro, como sugerido por Anderson e Smith (1995). Aplicando-se o algoritmo desses autores, obteve-se pressão máxima de cristalização da Mg-hornblenda de 6,6 kbar para os cristais das rochas do BRJ e de 5,8 kbar para os cristais dos enclaves (Figura 8B). As pressões obtidas foram utilizadas para estimar a temperatura solidus, aplicando o geotermômetro hornblenda-plagioclásio, utilizando a calibração de Holland e Blundy (1994) para rochas saturadas em sílica, com incerteza de $\pm 40^{\circ} \mathrm{C}$. Obteve-se a temperatura máxima de $826^{\circ} \mathrm{C}$ para os cristais da $\mathrm{FI}, 808^{\circ} \mathrm{C}$ para a FP e $870^{\circ} \mathrm{C}$ para os cristais dos enclaves. Anderson e Smith (1995) utilizaram ainda a correlação entre $\mathrm{Fe} /(\mathrm{Fe}+\mathrm{Mg})$ e ${ }^{\mathrm{IV}} \mathrm{Al}$ nos cristais de hornblenda para inferir as condições de fugacidade de oxigênio no magma durante a formação do

Tabela 2. Composições representativas de cristais de feldspatos do Batólito Rio Jacaré. Fórmula estrutural calculada com base em oito oxigênios.

\begin{tabular}{|c|c|c|c|c|c|c|c|c|c|c|}
\hline \multicolumn{6}{|c|}{ Fácies Inequigranular } & \multicolumn{3}{|c|}{ Fácies Porfirítica } & \multicolumn{2}{|c|}{ Enclaves } \\
\hline Amostra & FDS 492 & SOS 843A & SOS 850A & SOS 866 & SOS 866 & FDS 495 & SOS 840A & SOS 844 & $\begin{array}{l}\text { SOS } \\
867 \mathrm{~B}\end{array}$ & $\begin{array}{c}\text { SOS } \\
871 \mathrm{~B} \\
\end{array}$ \\
\hline $\mathrm{SiO}_{2}$ & 60,5 & 63,1 & 62,0 & 66,7 & 65,0 & 62,1 & 65,1 & 64,4 & 59,4 & 61,6 \\
\hline $\mathrm{Al}_{2} \mathrm{O}_{3}$ & 25,3 & 23,7 & 24,4 & 21,0 & 18,3 & 24,0 & 18,8 & 22,5 & 26,0 & 24,4 \\
\hline $\mathrm{CaO}$ & 6,1 & 3,7 & 4,9 & 1,5 & & 5,0 & & 3,1 & 7,1 & 5,4 \\
\hline $\mathrm{Na}_{2} \mathrm{O}$ & 8,1 & 9,2 & 8,7 & 10,8 & 0,4 & 8,9 & 1,1 & 9,9 & 7,4 & 8,6 \\
\hline $\mathrm{K}_{2} \mathrm{O}$ & & 0,2 & & & 16,4 & 0,0 & 15,1 & & & \\
\hline Total & 100,0 & 99,9 & 100,0 & 100,0 & 100,1 & 100,0 & 100,1 & 99,9 & 99,9 & 100,0 \\
\hline $\mathrm{Si}$ & 2,687 & 2,787 & 2,743 & 2,922 & 3,002 & 2,751 & 2,991 & 2,839 & 2,647 & 2,731 \\
\hline $\mathrm{Al}$ & 1,324 & 1,234 & 1,272 & 1,084 & 0,996 & 1,253 & 1,018 & 1,169 & 1,365 & 1,275 \\
\hline $\mathrm{Ca}$ & 0,290 & 0,175 & 0,232 & 0,070 & & 0,237 & & 0,146 & 0,339 & 0,257 \\
\hline $\mathrm{Na}$ & 0,698 & 0,788 & 0,746 & 0,917 & 0,036 & 0,764 & 0,098 & 0,846 & 0,639 & 0,739 \\
\hline K & & 0,011 & & & 0,966 & & 0,885 & & & \\
\hline Total & 4,999 & 4,995 & 4,993 & 4,993 & 5,000 & 5,005 & 4,992 & 5,000 & 4,990 & 5,002 \\
\hline Or & & 1,1 & & & 96,4 & & 90,0 & & & \\
\hline $\mathrm{Ab}$ & 70,6 & 80,9 & 76,3 & 92,9 & 3,6 & 76,3 & 10,0 & 85,3 & 65,3 & 74,2 \\
\hline $\mathrm{Na}$ & 29,4 & 18,0 & 23,7 & 7,1 & & 23,7 & & 14,7 & 34,7 & 25,8 \\
\hline
\end{tabular}

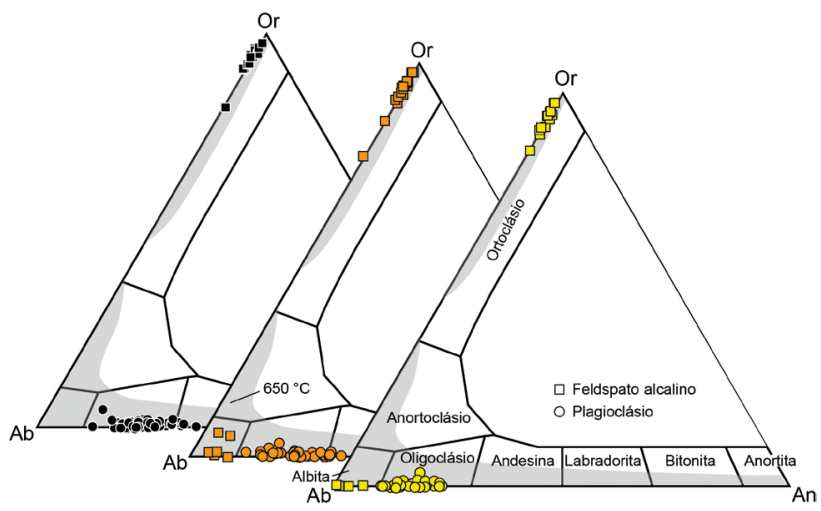

Figura 5. Composição dos feldspatos do Batólito Rio Jacaré no diagrama Or-Ab-An. Fácies Inequigranular (cor laranja); Fácies Porfirítica (cor amarela); e enclaves (cor preta). A área em cinza corresponde ao campo experimental para composições de feldspatos em equilíbrio na temperatura de $650^{\circ} \mathrm{C}$ (Fuhrman e Lindslay, 1988; Elkins e Grove, 1990).

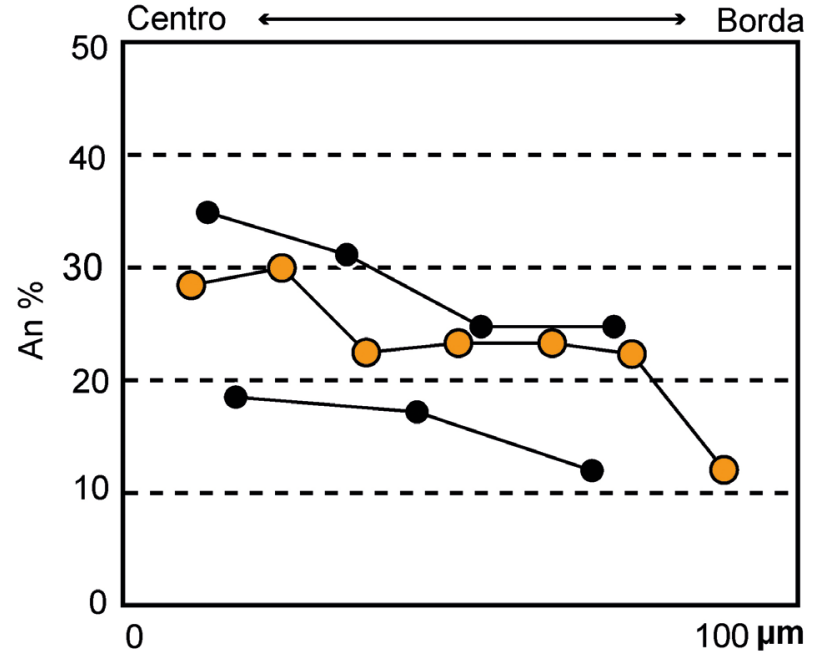

Figura 6. Perfis composicionais de cristais de plagioclásio do Batólito Rio Jacaré. Fácies Inequigranular (círculos laranja); enclaves (círculos pretos). 
anfibólio. Ao utilizar esses critérios, nota-se que os cristais de Mg-hornblenda do BRJ e seus enclaves cristalizaram-se sob condições de alta fugacidade de oxigênio (Figura 8C).

\section{Epídoto}

Os dados químicos dos cristais de epídoto (Tabela 5) permitem classificá-los quanto a sua gênese, utilizando os intervalos dos valores da molécula de pistacita $\left[\mathrm{Ps}=\mathrm{Fe}^{3+}\right.$ ) $\left.\left(\mathrm{Fe}^{3+}+\mathrm{Al}\right) \times 100\right]$ especificados por Tulloch $(1979,1986)$. Aqueles com \%Ps entre 0 e $24 \%$ correspondem a cristais de epídoto formados a partir da alteração do plagioclásio; entre 36 e $48 \%$, formados a partir da desestabilização da biotita; e entre 25 e $29 \%$ são considerados magmáticos. No histograma da Figura 9, nota-se que os cristais de epídoto da FP são magmáticos e formados a partir da alteração do plagioclásio, os da FI são magmáticos e de alteração do plagioclásio e da biotita, e os cristais pertencentes aos enclaves possuem gênese magmática.

\section{LITOGEOQUÍMICA}

Um total de 39 amostras representativas, sendo 29 do BRJ e 11 dos enclaves, foi selecionado para análises químicas de elementos maiores e menores (Tabela 6). A perda ao fogo foi obtida por calcinação das amostras a $1.000^{\circ} \mathrm{C}$. Em 17 dessas rochas foram dosados alguns elementos-traço (Tabela 7). A determinação dos elementos maiores foi feita utilizando a fluorescência de raios-X, no CLGeo-UFS, e as análises de elementos traços foram obtidas no ACME Analytical Laboratories LTDA., em Vancouver, Canadá, e na SGS GEOSOL, em Minas Gerais, Brasil, utilizando o ICP-MS.

O BRJ possui conteúdos de $\mathrm{SiO}_{2}$ na FI que variam de 56 a $72 \%$, e na FP, de 65 a $70 \%$. Essas rochas posicionam-se no diagrama TAS (Figura 10A) nos campos do monzonito, do granodiorito e do granito. Por outro lado, os conteúdos de $\mathrm{SiO}_{2}$ dos EMM variam de 48 a $67 \%$ e posiciona-os nos campos do gabro, do monzonito e do granito (Figura 10A).

Tabela 3. Análises químicas representativas de cristais de biotita do Batólito Rio Jacaré. Fórmula estrutural calculada com base em 22 oxigênios. O percentual de $\mathrm{H}_{2} \mathrm{O}^{*}$ foi obtido por estequiometria.

\begin{tabular}{|c|c|c|c|c|c|c|c|c|c|c|c|}
\hline \multicolumn{7}{|c|}{ Fácies Inequigranular } & \multicolumn{3}{|c|}{ Fácies Porfirítica } & \multicolumn{2}{|c|}{ Enclaves } \\
\hline & FDS 496A & SOS 836 & SOS 849 & SOS 850A & SOS 864 & SOS 866 & FDS 495 & SOS 837 & SOS 844 & SOS 861Q & SOS $876 \mathrm{~B}$ \\
\hline $\mathrm{SiO}_{2}$ & 37,8 & 39,5 & 39,4 & 39,1 & 38,7 & 38,9 & 38,3 & 39,9 & 38,2 & 38,3 & 37,7 \\
\hline $\mathrm{TiO}_{2}$ & 2,2 & 1,7 & 2,3 & 1,7 & 1,7 & 1,4 & 1,5 & 1,2 & 2,0 & 1,3 & 2,8 \\
\hline $\mathrm{Al}_{2} \mathrm{O}_{3}$ & 15,4 & 16,5 & 16,3 & 15,9 & 15,8 & 15,6 & 15,6 & 15,9 & 16,1 & 15,2 & 15,3 \\
\hline $\mathrm{FeO}$ & 18,6 & 16,0 & 15,2 & 15,5 & 16,6 & 16,7 & 17,8 & 15,9 & 17,3 & 18,1 & 18,5 \\
\hline $\mathrm{MnO}$ & 0,6 & 0,2 & 0,3 & 0,1 & 0,2 & 0,3 & & 0,4 & 0,3 & 0,3 & 0,4 \\
\hline $\mathrm{MgO}$ & 11,8 & 13,1 & 12,8 & 14,0 & 13,9 & 13,4 & 12,8 & 13,2 & 12,1 & 13,4 & 11,8 \\
\hline $\mathrm{K}_{2} \mathrm{O}$ & 9,5 & 8,8 & 8,9 & 9,5 & 9,8 & 9,5 & 9,7 & 9,4 & 10,0 & 8,5 & 9,4 \\
\hline$F^{2}$ & 0,1 & 0,2 & 0,5 & 0,5 & 0,8 & 0,6 & 0,2 & 0,9 & & 0,7 & 0,7 \\
\hline $\mathrm{Cl}$ & & & & 0,1 & & & & 0,1 & & & \\
\hline $\mathrm{H}_{2} \mathrm{O}^{*}$ & 3,9 & 3,9 & 3,8 & 3,8 & 3,6 & 3,7 & 3,9 & 3,6 & 4,0 & 3,6 & 3,6 \\
\hline $\mathrm{O}=\mathrm{F}, \mathrm{Cl}$ & & $-0,1$ & $-0,2$ & $-0,2$ & $-0,3$ & $-0,2$ & $-0,1$ & $-0,4$ & & $-0,3$ & $-0,3$ \\
\hline Total & 99,9 & 99,9 & 99,4 & 100,1 & 100,2 & 100,0 & 99,8 & 100,3 & 100,0 & 99,4 & 100,1 \\
\hline $\mathrm{Si}$ & 5,705 & 5,811 & 5,827 & 5,770 & 5,757 & 5,783 & 5,743 & 5,884 & 5,716 & 5,751 & 5,676 \\
\hline$A I^{I V}$ & 2,295 & 2,189 & 2,173 & 2,229 & 2,243 & 2,217 & 2,257 & 2,116 & 2,284 & 2,248 & 2,324 \\
\hline$[Z]$ & 8,000 & 8,000 & 8,000 & 8,000 & 8,000 & 8,000 & 8,000 & 8,000 & 8,000 & 8,000 & 8,000 \\
\hline $\mathrm{Al}^{\mathrm{Vl}}$ & 0,436 & 0,678 & 0,668 & 0,545 & 0,417 & 0,527 & 0,508 & 0,651 & 0,560 & 0,453 & 0,400 \\
\hline $\mathrm{Ti}$ & 0,250 & 0,191 & 0,256 & 0,192 & 0,193 & 0,161 & 0,173 & 0,138 & 0,227 & 0,152 & 0,315 \\
\hline $\mathrm{Fe}$ & 2,349 & 1,975 & 1,885 & 1,921 & 2,067 & 2,078 & 2,239 & 1,963 & 2,162 & 2,278 & 2,331 \\
\hline $\mathrm{Mn}$ & 0,073 & 0,024 & 0,036 & 0,012 & 0,024 & 0,036 & 0,000 & 0,048 & 0,036 & 0,036 & 0,049 \\
\hline $\mathrm{Mg}$ & 2,655 & 2,866 & 2,811 & 3,086 & 3,088 & 2,980 & 2,854 & 2,909 & 2,697 & 3,008 & 2,648 \\
\hline$[Y]$ & 5,764 & 5,734 & 5,656 & 5,755 & 5,790 & 5,782 & 5,774 & 5,710 & 5,683 & 5,928 & 5,744 \\
\hline K & 1,828 & 1,659 & 1,682 & 1,790 & 1,858 & 1,803 & 1,854 & 1,768 & 1,905 & 1,636 & 1,805 \\
\hline$[X]$ & 1,828 & 1,659 & 1,682 & 1,790 & 1,858 & 1,803 & 1,854 & 1,768 & 1,905 & 1,636 & 1,805 \\
\hline $\mathrm{OH}^{*}$ & 3,952 & 3,907 & 3,766 & 3,741 & 3,623 & 3,718 & 3,905 & 3,556 & 4,000 & 3,667 & 3,667 \\
\hline $\mathrm{F}$ & 0,048 & 0,093 & 0,233 & 0,233 & 0,376 & 0,282 & 0,095 & 0,419 & & 0,332 & 0,333 \\
\hline $\mathrm{Cl}$ & & & & 0,025 & & & & 0,025 & & & \\
\hline$M]$ & 4,000 & 4,000 & 4,000 & 4,000 & 4,000 & 4,000 & 4,000 & 4,000 & 4,000 & 4,000 & 4,000 \\
\hline Total & 19,593 & 19,394 & 19,337 & 19,546 & 19,648 & 19,585 & 19,628 & 19,478 & 19,588 & 19,564 & 19,549 \\
\hline
\end{tabular}


O conteúdo do total de álcalis $\left(\mathrm{K}_{2} \mathrm{O}+\mathrm{Na}_{2} \mathrm{O}\right)$ dessas rochas é maior que 6,5\% (Figura $10 \mathrm{~A}$ ), e a razão $\mathrm{K}_{2} \mathrm{O} / \mathrm{Na}_{2} \mathrm{O}$ está compreendida entre 0,5 e 1,8 para a FI, entre 0,9 e 1,3 para a FP, e entre 0,4 e 1,4 para os enclaves. As rochas do $\mathrm{BRJ}$ são predominantemente metaluminosas, apresentam tendência para termos peraluminosos (Figura 10B) e posicionam-se no campo dos granitos do tipo I de Chappell e White (1992).

No diagrama $\mathrm{K}_{2} \mathrm{O}$ versus $\mathrm{SiO}_{2}$ com campos de Peccerillo e Taylor (1976), as amostras do BRJ alocam-se no campo das rochas calcioalcalinas de alto $\mathrm{K}$, e aquelas que apresentam conteúdos de $\mathrm{SiO}_{2}$ superiores a $65 \%$ exibem aumento significativo no conteúdo de $\mathrm{K}_{2} \mathrm{O}$. Os EMM alocam-se predominantemente no campo shoshonítico (Figura 10C) e possuem características típicas da associação shoshonítica descrita por Morrison (1980), por exemplo, total de álcalis alto $\left(\mathrm{K}_{2} \mathrm{O}+\mathrm{Na}_{2} \mathrm{O}>5 \%\right)$, baixo $\mathrm{TiO}_{2}(<1,3 \%)$ e alto alumínio (14-19\%).

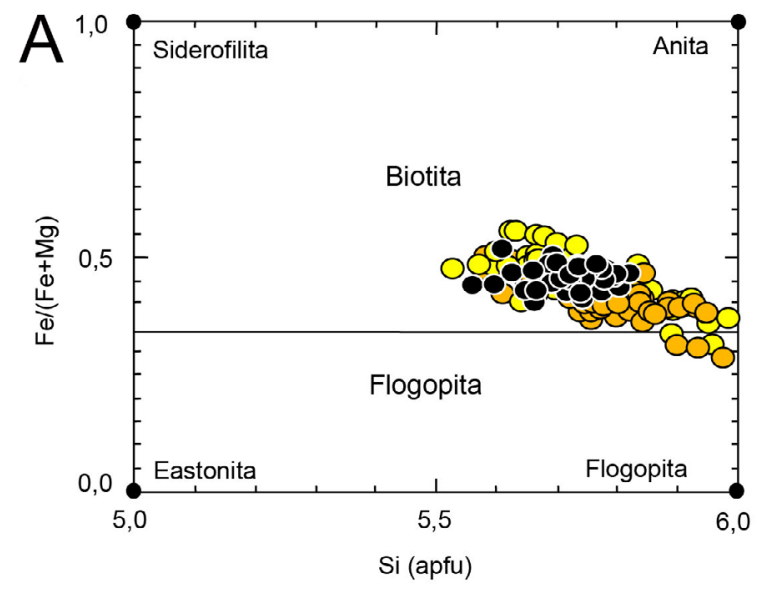

Ao utilizar o modified álcali-lime index (MALI) (Frost et al., 2001), notou-se que as rochas do BRJ apresentam afinidade com a Série Álcali-Cálcica, tendo rochas que se posicionam igualmente nos campos das séries Alcalina e Calcioalcalina (Figura 10D). Os conteúdos de FeOt e MgO das amostras estudadas são característicos de rochas da Série Magnesiana (Figura 11).

Nos diagramas de Harker (Figura 12), as rochas estudadas exibem trends negativos para $\mathrm{TiO}_{2}, \mathrm{MgO}, \mathrm{CaO}, \mathrm{P}_{2} \mathrm{O}_{3} \mathrm{e}$ $\mathrm{FeOt}$, que sugerem o fracionamento de plagioclásio, hornblenda, apatita, titanita e minerais opacos. Além disso, nota-se a forma retilínea nos trends negativos de $\mathrm{CaO}$, $\mathrm{FeOt}$ e $\mathrm{MgO}$, o que sugere a presença de mistura entre magmas félsico e máfico. Observam-se ainda dois trends positivos distintos para $\mathrm{o} \mathrm{K}_{2} \mathrm{O}$, um das rochas do $\mathrm{BRJ}$ e o outro dos enclaves.

Os padrões de elementos terras raras (ETR) das amostras das diferentes fácies do BRJ (Figura 13) são similares e
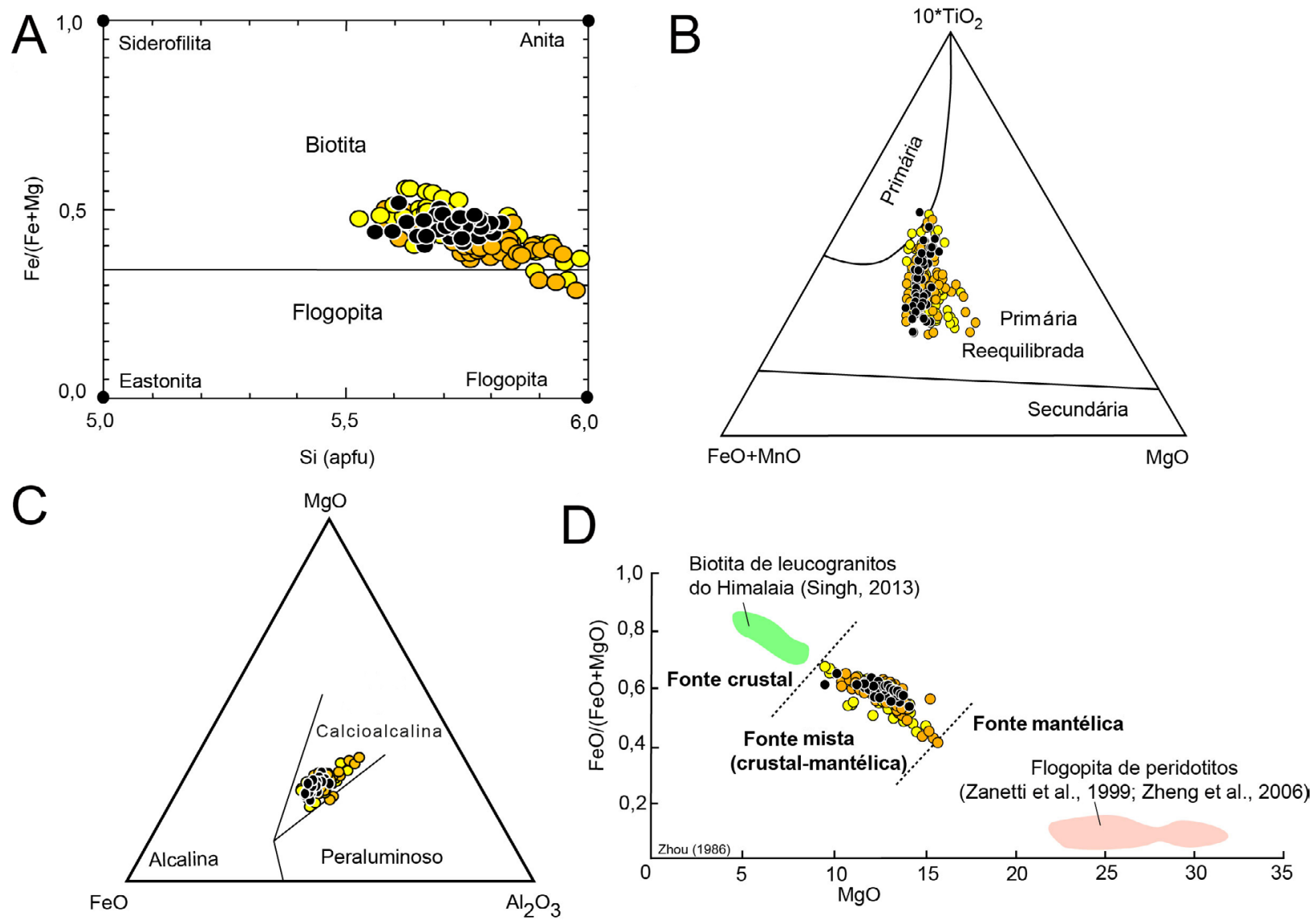

Figura 7. Diagramas com dados dos cristais de biotita de rochas do Batólito Rio Jacaré. (A) Quadrilátero de classificação para biotita (Deer et al., 1992); (B) triângulo discriminante de biotita primária, primária reequilibrada e secundária (Nachit et al., 2005); (C) triângulo FeO-MgO-TiO 2 (Abdel-Rahman, 1994); (D) variação na razão $\mathrm{FeO} /(\mathrm{FeO}+\mathrm{MgO}$ ) e $\mathrm{MgO}$ dos cristais de biotita (Zhou, 1986). Fácies Inequigranular (círculos laranja); Fácies Porfirítica (círculos amarelos); enclaves (círculos pretos). 
mostram enriquecimento dos terras raras leves (ETRL) em relação aos terras raras pesados (ETRP). As razões [La/Yb] ${ }_{\mathrm{N}}$ variam de 13,56 a 133,09 para as rochas da FI, de 18,75 a 28,13 para a FP, e de 6,54 a 22,40 para os enclaves. As razões de $[\mathrm{La} / \mathrm{Sm}]_{\mathrm{N}}$ estão compreendidas nas rochas da FI entre 3,17 e 7,64, entre 3,82 e 4,91 na FP, e entre 2,32 e 2,59 nos enclaves. Esse batólito apresenta moderadas anomalias negativas de $\mathrm{Eu}$, com razões $\left(\mathrm{Eu} / \mathrm{Eu}^{*}\right)$ variando de 0,65 a 0,89 e os enclaves entre 0,68 e 0,97 , sugerindo que o plagioclásio foi fracionado durante a evolução desses magmas. Observa-se ainda que os enclaves, apesar de serem menos evoluídos, são mais ricos em ETR.
No diagrama multielementar normalizado pelo condrito de Thompson (1982), constatam-se picos em Rb, Th e K nas amostras do BRJ e vales de $\mathrm{Nb}, \mathrm{Ta}, \mathrm{Sr}, \mathrm{P}$ e Ti. Os enclaves mostram feições similares com as rochas do BRJ, porém diferem-se pela presença de vales em Th e pelo pico de $\mathrm{P}$ (Figura 13) que pode indicar fracionamento precoce de fases ricas em Th e acumulação em apatita.

As amostras analisadas possuem teores de $\mathrm{Y}(4,10 \mathrm{a}$ $24,23 \mathrm{ppm}), \mathrm{Nb}$ (4,38 a 16,60 ppm) e Rb (77,1 a 208,4 ppm) que as alocam no campo dos magmatismos gerados em ambientes de arco vulcânico em um período pós-colisional (Figura 14), segundo o diagrama de Pearce et al. (1984) e Pearce (1996).

Tabela 4. Análises químicas pontuais representativas de cristais de anfibólio das rochas do Batólito Rio Jacaré. Cálculo da fórmula estrutural com base em 23 oxigênios. O conteúdo do $\mathrm{H}_{2} \mathrm{O}^{\star}$ foi obtido por estequiometria.

\begin{tabular}{|c|c|c|c|c|c|c|c|c|c|c|c|}
\hline \multicolumn{6}{|c|}{ Fácies Inequigranular } & \multicolumn{3}{|c|}{ Fácies Porfirítica } & \multicolumn{3}{|c|}{ Enclaves } \\
\hline & $\begin{array}{l}\text { SOS } \\
836\end{array}$ & $\begin{array}{l}\text { SOS } \\
849 A\end{array}$ & $\begin{array}{l}\text { SOS } \\
850 A\end{array}$ & $\begin{array}{l}\text { FDS } \\
492\end{array}$ & $\begin{array}{l}\text { SOS } \\
864\end{array}$ & $\begin{array}{l}\text { SOS } \\
847\end{array}$ & $\begin{array}{c}\text { FDS } \\
495 \\
\end{array}$ & $\begin{array}{c}\text { FDS } \\
485\end{array}$ & $\begin{array}{l}\text { SOS } \\
871 B\end{array}$ & $\begin{array}{c}\text { SOS } \\
861 C\end{array}$ & $\begin{array}{c}\text { SOS } \\
861 M\end{array}$ \\
\hline $\mathrm{SiO}_{2}$ & 49,0 & 46,2 & 45,5 & 45,0 & 44,9 & 49,0 & 45,8 & 46,6 & 45,0 & 46,0 & 45,7 \\
\hline $\mathrm{TiO}_{2}^{2}$ & 0,5 & 0,9 & 0,8 & 1,7 & 1,1 & 0,7 & 1,4 & 1,3 & 0,9 & 0,7 & 1,0 \\
\hline $\mathrm{Al}_{2} \mathrm{O}_{3}$ & 8,6 & 10,8 & 9,8 & 8,7 & 8,9 & 8,5 & 8,0 & 7,8 & 10,2 & 8,2 & 9,1 \\
\hline $\mathrm{Fe}_{2} \mathrm{O}_{3}$ & 3,4 & 2,7 & 3,6 & 4,5 & 5,1 & 3,9 & 7,5 & 7,6 & 6,3 & 5,5 & 4,9 \\
\hline $\mathrm{FeO}$ & 10,9 & 12,7 & 12,8 & 12,4 & 13,3 & 10,6 & 11,0 & 10,9 & 10,8 & 12,6 & 11,3 \\
\hline $\mathrm{MnO}$ & 0,2 & 0,2 & 0,3 & 0,4 & 0,4 & 0,3 & 0,7 & 0,4 & 0,4 & 0,5 & 0,4 \\
\hline $\mathrm{MgO}$ & 12,5 & 11,0 & 11,2 & 11,5 & 10,8 & 12,2 & 11,2 & 11,3 & 11,3 & 11,2 & 12,0 \\
\hline $\mathrm{CaO}$ & 11,0 & 10,8 & 11,5 & 11,4 & 11,6 & 10,3 & 11,5 & 11,7 & 11,2 & 11,3 & 11,6 \\
\hline $\mathrm{Na}_{2} \mathrm{O}$ & 1,4 & 1,7 & 1,5 & 1,7 & 1,4 & 1,6 & 0,7 & & 1,4 & 1,7 & 1,5 \\
\hline $\mathrm{K}_{2} \mathrm{O}$ & 0,8 & 1,2 & 1,2 & 1,1 & 1,1 & 1,0 & 1,0 & 1,0 & 1,3 & 0,9 & 1,0 \\
\hline $\mathrm{F}$ & & & & & 0,3 & & & & 0,3 & & 0,1 \\
\hline $\mathrm{Cl}$ & & & & 0,1 & 0,1 & & & & & & \\
\hline $\mathrm{H}_{2} \mathrm{O}^{*}$ & 2,1 & 2,0 & 2,0 & 2,0 & 1,8 & 2,1 & 2,0 & 2,0 & 1,9 & 2,0 & 2,0 \\
\hline $\mathrm{O}=\mathrm{F}, \mathrm{Cl}$ & & & & & $-0,1$ & & & & $-0,1$ & & \\
\hline Total & 100,4 & 100,2 & 100,1 & 100,5 & 100,7 & 100,3 & 100,8 & 100,7 & 100,7 & 100,7 & 100,6 \\
\hline $\mathrm{Si}$ & 7,068 & 6,774 & 6,721 & 6,650 & 6,660 & 7,081 & 6,742 & 6,828 & 6,603 & 6,796 & 6,697 \\
\hline \multirow[t]{2}{*}{ Alv } & 0,931 & 1,226 & 1,279 & 1,349 & 1,339 & 0,919 & 1,258 & 1,172 & 1,397 & 1,203 & 1,302 \\
\hline & 8,000 & 8,000 & 8,000 & 8,000 & 8,000 & 8,000 & 8,000 & 8,000 & 8,000 & 8,000 & 8,000 \\
\hline All & 0,535 & 0,634 & 0,428 & 0,170 & 0,220 & 0,533 & 0,134 & 0,180 & 0,366 & 0,228 & 0,273 \\
\hline $\mathrm{Ti}$ & 0,053 & 0,097 & 0,087 & 0,196 & 0,120 & 0,074 & 0,152 & 0,140 & 0,097 & 0,076 & 0,108 \\
\hline $\mathrm{Fe}^{3+}$ & 0,370 & 0,294 & 0,402 & 0,504 & 0,572 & 0,430 & 0,829 & 0,839 & 0,692 & 0,617 & 0,547 \\
\hline $\mathrm{Fe}^{2+}$ & 1,321 & 1,553 & 1,584 & 1,531 & 1,654 & 1,287 & 1,351 & 1,332 & 1,329 & 1,560 & 1,388 \\
\hline $\mathrm{Mn}$ & 0,024 & 0,024 & 0,037 & 0,049 & 0,049 & 0,036 & 0,085 & 0,048 & 0,049 & 0,061 & 0,049 \\
\hline \multirow[t]{2}{*}{$\mathrm{Mg}$} & 2,697 & 2,396 & 2,461 & 2,549 & 2,385 & 2,639 & 2,448 & 2,459 & 2,466 & 2,457 & 2,635 \\
\hline & 5,000 & 5,000 & 5,000 & 5,000 & 5,000 & 5,000 & 5,000 & 5,000 & 5,000 & 5,000 & 5,000 \\
\hline $\mathrm{Ca}$ & 1,696 & 1,691 & 1,816 & 1,801 & 1,854 & 1,593 & 1,806 & 1,844 & 1,757 & 1,782 & 1,832 \\
\hline $\mathrm{Na}$ & 0,384 & 0,501 & 0,421 & 0,477 & 0,395 & 0,439 & 0,195 & & 0,390 & 0,477 & 0,418 \\
\hline \multirow[t]{2}{*}{ K } & 0,144 & 0,220 & 0,222 & 0,203 & 0,204 & 0,181 & 0,184 & 0,183 & 0,238 & 0,166 & 0,183 \\
\hline & 2,224 & 2,412 & 2,459 & 2,482 & 2,453 & 2,213 & 2,185 & 2,027 & 2,386 & 2,424 & 2,434 \\
\hline $\mathrm{F}$ & & & & & 0,141 & & & & 0,139 & & 0,046 \\
\hline $\mathrm{Cl}$ & & & & 0,025 & 0,025 & & & & & & \\
\hline \multirow[t]{2}{*}{$\mathrm{OH}^{*}$} & 2,000 & 2,000 & 2,000 & 1,975 & 1,834 & 2,000 & 2,000 & 2,000 & 1,861 & 2,000 & 1,953 \\
\hline & 2,000 & 2,000 & 2,000 & 2,000 & 2,000 & 2,000 & 2,000 & 2,000 & 2,000 & 2,000 & 2,000 \\
\hline Total & 17,22 & 17,412 & 17,459 & 17,482 & 17,453 & 17,213 & 17,185 & 17,027 & 17,386 & 17,424 & 17,434 \\
\hline
\end{tabular}




\section{GEOCRONOLOGIA U-PB SHRIMP}

A idade de cristalização do BRJ foi determinada utilizando-se a amostra FDS-492, que corresponde a um hornblenda biotita granodiorito (UTM: 0633449/8908274) da FI (FDS 492). O método utilizado foi $\mathrm{U}-\mathrm{Pb}_{\text {SHRIMP }}$ em zircão e a determinação foi feita no Laboratório de Geocronologia de Alta Resolução do Instituto de Geociências da Universidade de São Paulo. A metodologia empregada neste estudo é descrita por Sato et al. (2014). Foram obtidas imagens de catodoluminescência de 83 cristais de zircão, dos quais 12 foram selecionados para serem analisados (Figura 15). As áreas escolhidas para análise não apresentavam fraturas ou alterações.
Os cristais de zircão analisados são euédricos, ligeiramente prismáticos, bipiramidais, apresentam zoneamentos e os tamanhos (maior comprimento) em torno de $200 \mu \mathrm{m}$. Essas formas são similares àquelas identificadas por Pupin (1980) em cristais formados em magmas com afinidade com a série calcioalcalina. Os teores de urânio desses cristais variam de 176 a 964 ppm; de tório, de 125 a 314 ppm; e a razão $\mathrm{Th} / \mathrm{U}$, de 0,33 a 0,92 (Tabela 8), que se situa no intervalo de valores considerados por Kirkland et al. (2015) como de cristais de zircão magmáticos.

As análises obtidas forneceram Concordia age de $617 \pm$ $4 \mathrm{Ma}$, com MSWD = 7,2 (Figura 16), e é considerada como a idade de cristalização do batólito.
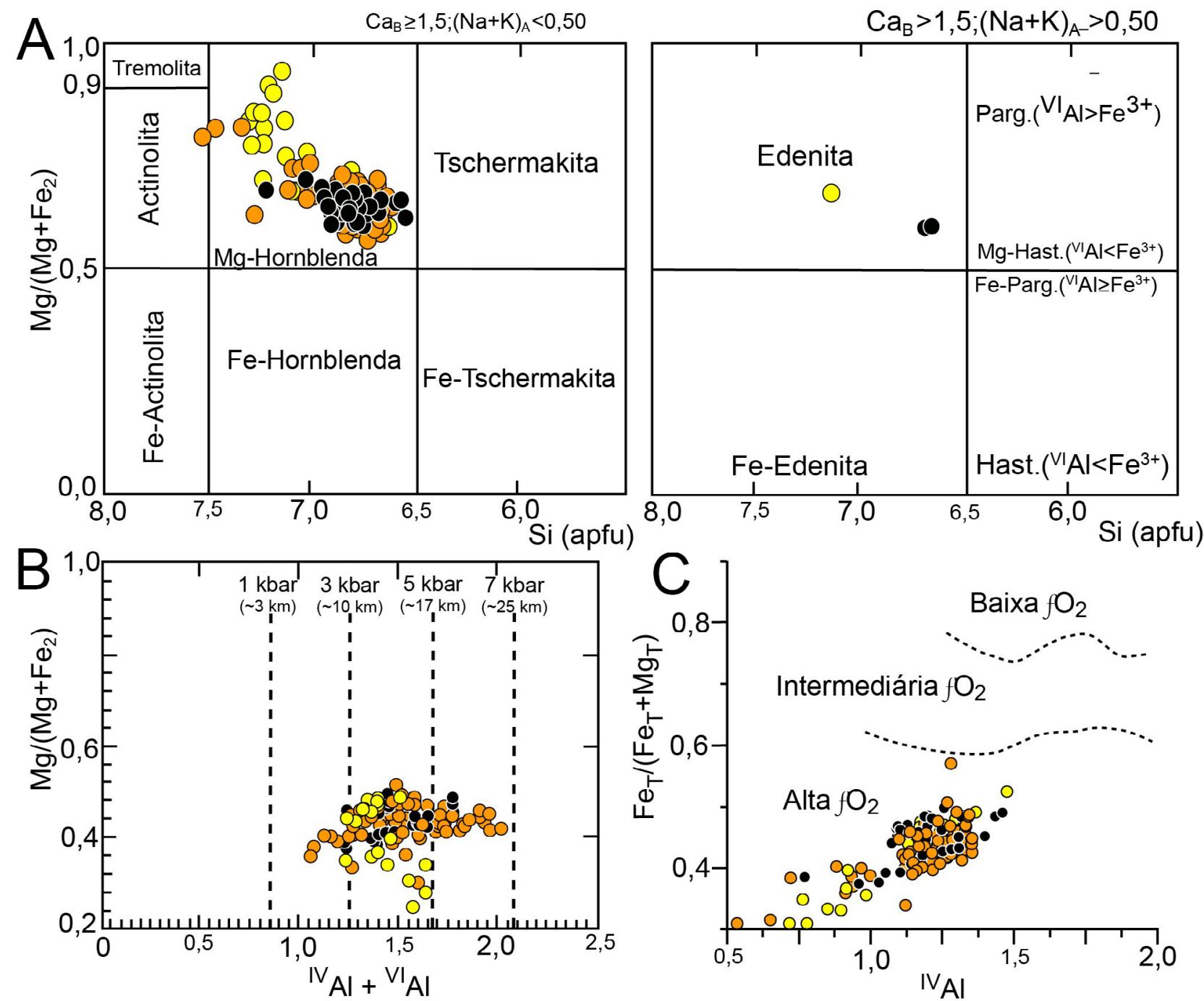

Figura 8. Diagramas com dados de anfibólios das rochas estudadas: (A) classificação de anfibólios cálcicos de Leake et al. (1997); (B) estimativa de pressão; (C) estimativa de fugacidade de oxigênio, segundo Anderson e Smith (1995). Fácies Inequigranular (círculos laranja); Fácies Porfirítica (círculos amarelos); e enclaves (círculos pretos). 


\section{DISCUSSÃO}

O BRJ, segundo Santos e Souza (1988), Brito (1996) e Teixeira et al. (2014), é caracterizado pela textura porfirítica. Neste estudo, identificou-se no BRJ a existência de duas fácies petrográficas distintas: a FI (predominante) e a FP. Ambas têm EMM, evidenciando que durante a cristalização e a estruturação do BRJ houve aportes de magmas máficos. A foliação de fluxo magmático presente nas rochas desse batólito tem direção variável, sendo observada tanto pela orientação dos enclaves máficos como pelos cristais de biotita e feldspatos.

Segundo Bonin (2004), enclaves máficos em granitos são manto-derivados e representam magma básico que se colocou na câmara magmática, enquanto ela ainda evoluía. Alguns autores (e.g., Vernon et al., 1988; Perugini e Poli, 2011) sugerem que as formas dos enclaves (e.g., em gotas, cúspides) com contatos bem delimitados e bordas de reação indicam a coexistência de, no mínimo, dois magmas. Koyaguchi (1986) chama a atenção para o fato que, quando a temperatura de equilíbrio entre os magmas é superior à temperatura do solidus, ocorre o mixing, gerando magma híbrido. Weidendorfer et al. (2014) propõem que o mixing ocorra quando a viscosidade entre os magmas coexistentes for similar. A multiplicidade de enclaves, observada em campo, escuros, claros e com variados tons de cinza (Figura 2D), sugere que o processo de mistura entre magmas no BRJ tenha ocorrido em vários momentos.

A associação de texturas como as encontradas nas rochas do BRJ (e.g., zoneamentos em cristais de plagioclásio, zonas de inclusões em fenocristais de feldspatos, biotita blade e cristais de apatita aciculares) é, segundo Hibbard (1991), característica de rochas formadas por mistura de magmas.
A presença de zoneamento normal nos cristais de plagioclásio dos EMM pode indicar a perda de calor, resultado da interação do magma máfico (enclaves) com o magma félsico. Por outro lado, zoneamentos oscilatório e inverso identificados nos cristais de plagioclásio dos granitos e dos granodioritos do BRJ podem refletir as variações térmicas provocadas quando da interação entre o magma máfico e o magma do BRJ, além de indicar a presença de vários pulsos magmáticos máficos, o que explicaria a existência de enclaves múltiplos identificados nesse batólito.

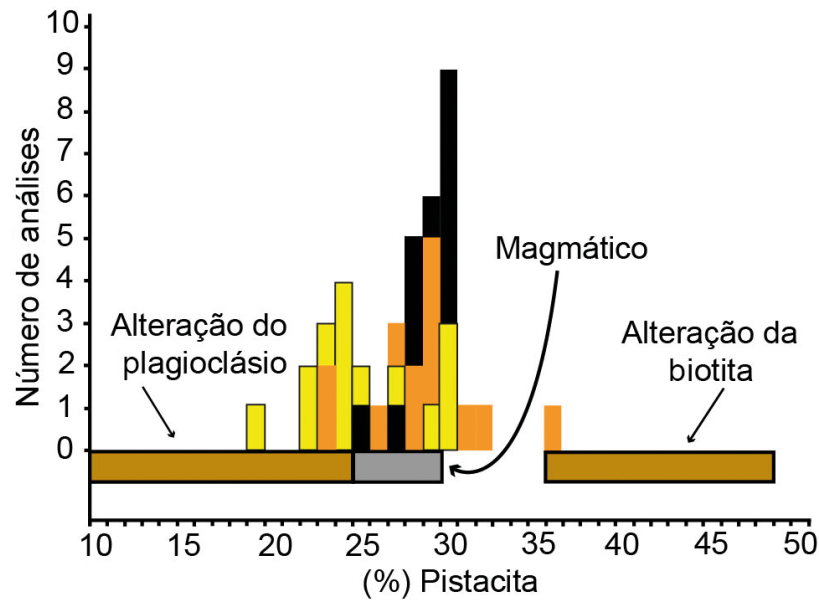

Figura 9. Histograma apresentando número de análises versus a porcentagem molar de pistacita em cristais de epídoto das rochas do Batólito Rio Jacaré. A variação composicional de epídotos de alteração do plagioclásio, da biotita e os magmáticos são de Tulloch $(1979,1986)$. Fácies Inequigranular (laranja), Fácies Porfirítica (amarelo) e enclaves (preto).

Tabela 5. Análises representativas de cristais de epídoto das rochas estudadas do Batólito Rio Jacaré. Cálculo da fórmula estrutural com base em 12,5 oxigênios.

\begin{tabular}{|c|c|c|c|c|c|c|c|c|c|c|c|c|}
\hline & \multicolumn{4}{|c|}{ Fácies Inequigranular } & \multicolumn{4}{|c|}{ Fácies Porfirítica } & \multicolumn{4}{|c|}{ Enclaves } \\
\hline & 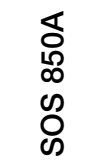 & 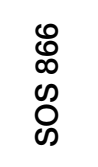 & $\begin{array}{l}\searrow \\
\nsubseteq \\
\mathscr{~} \\
\varnothing\end{array}$ & 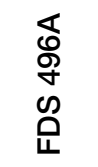 & 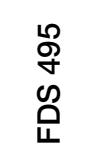 & 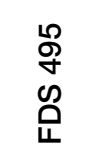 & $\begin{array}{l}\text { \& } \\
\infty \\
\text { D } \\
\infty\end{array}$ & $\begin{array}{l}\text { ఫे } \\
\infty \\
\mathscr{D} \\
\mathscr{\infty}\end{array}$ & 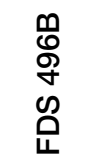 & $\begin{array}{l}0 \\
0 \\
\infty \\
0 \\
0 \\
\infty\end{array}$ & $\begin{array}{l}0 \\
\frac{0}{0} \\
\infty \\
0 \\
0\end{array}$ & $\begin{array}{l}\mathscr{0} \\
\mathbb{\infty} \\
\infty \\
\mathscr{~} \\
\mathscr{\leftrightarrow}\end{array}$ \\
\hline $\mathrm{SiO}_{2}$ & 41,1 & 39,0 & 39,5 & 39,1 & 39,2 & 39,6 & 42,0 & 42,1 & 39,0 & 40,0 & 40,7 & 38,8 \\
\hline $\mathrm{Al}_{2} \mathrm{O}_{3}$ & 25,5 & 23,8 & 23,3 & 24,1 & 23,4 & 23,4 & 25,0 & 24,5 & 23,2 & 23,9 & 25,0 & 24,1 \\
\hline $\mathrm{FeO}$ & 11,4 & 13,4 & 13,6 & 12,9 & 13,7 & 13,9 & 11,1 & 11,7 & 14,0 & 13,1 & 12,3 & 13,0 \\
\hline $\mathrm{CaO}$ & 22,0 & 23,8 & 23,6 & 23,9 & 23,7 & 23,1 & 22,0 & 21,7 & 23,9 & 22,9 & 22,1 & 24,1 \\
\hline Total & 100,0 & 100,0 & 100,0 & 100,0 & 100,0 & 100,0 & 100,1 & 100,0 & 100,1 & 99,9 & 100,1 & 100,0 \\
\hline $\mathrm{Si}$ & 3,203 & 3,109 & 3,148 & 3,109 & 3,129 & 3,154 & 3,260 & 3,278 & 3,118 & 3,170 & 3,188 & 3,091 \\
\hline $\mathrm{Al}$ & 2,342 & 2,236 & 2,188 & 2,259 & 2,201 & 2,197 & 2,287 & 2,248 & 2,186 & 2,232 & 2,308 & 2,263 \\
\hline $\mathrm{Fe}^{2+}$ & 0,743 & 0,893 & 0,906 & 0,858 & 0,914 & 0,926 & 0,720 & 0,762 & 0,936 & 0,868 & 0,806 & 0,866 \\
\hline $\mathrm{Ca}$ & 1,837 & 2,272 & 2,015 & 2,036 & 2,027 & 1,971 & 1,829 & 1,810 & 2,048 & 1,944 & 1,855 & 2,057 \\
\hline Total & 8,125 & 8,510 & 8,257 & 8,262 & 8,271 & 8,248 & 8,096 & 8,098 & 8,288 & 8,214 & 8,157 & 8,277 \\
\hline \%Ps & 24,1 & 28,5 & 29,3 & 27,5 & 29,4 & 29,7 & 24,0 & 25,3 & 30,0 & 28,0 & 25,9 & 27,7 \\
\hline
\end{tabular}


Tabela 6. Análises químicas de elementos maiores e menores das rochas do Batólito Rio Jacaré.

\begin{tabular}{|c|c|c|c|c|c|c|c|c|c|c|c|c|c|c|c|}
\hline \multicolumn{16}{|c|}{ Fácies Inequigranular } \\
\hline & $\begin{array}{l}\text { FDS } \\
261 A\end{array}$ & $\begin{array}{l}\text { FDS } \\
265\end{array}$ & $\begin{array}{l}\text { FDS } \\
266\end{array}$ & $\begin{array}{l}\text { FDS } \\
492\end{array}$ & $\begin{array}{l}\text { FDS } \\
493\end{array}$ & $\begin{array}{l}\text { SOS } \\
836\end{array}$ & $\begin{array}{l}\text { SOS } \\
841\end{array}$ & $\begin{array}{l}\text { SOS } \\
843\end{array}$ & $\begin{array}{l}\text { SOS } \\
845\end{array}$ & $\begin{array}{l}\text { SOS } \\
849 A\end{array}$ & $\begin{array}{l}\text { SOS } \\
850 A\end{array}$ & & $\begin{array}{l}\text { OS } \\
54\end{array}$ & $\begin{array}{l}\text { SOS } \\
873 \mathrm{~A}\end{array}$ & $\begin{array}{l}\text { SOS } \\
876 A\end{array}$ \\
\hline \multirow{2}{*}{ UTM } & $\begin{array}{l}\stackrel{8}{0} \\
\text { ஸे } \\
\text { ปे }\end{array}$ & \begin{tabular}{l}
0 \\
\multirow{8}{*}{} \\
f
\end{tabular} & $\begin{array}{l}\bar{N} \\
\text { f } \\
0\end{array}$ & 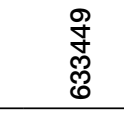 & 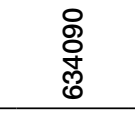 & 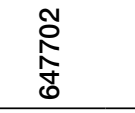 & 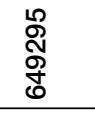 & $\begin{array}{l}\qquad \\
\frac{8}{8} \\
0\end{array}$ & 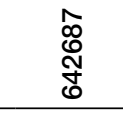 & $\begin{array}{l}\text { ధ్ } \\
\text { ᄋ్ } \\
\text { ర్ }\end{array}$ & 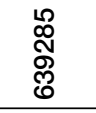 & & 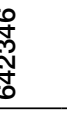 & \begin{tabular}{l}
$\infty$ \\
\multirow{N}{*}{} \\
స్ \\
\end{tabular} & $\begin{array}{l}\text { ڤ్ } \\
\text { ల్ర్ } \\
\text { ర్ }\end{array}$ \\
\hline & 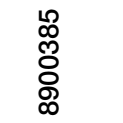 & $\begin{array}{l}\text { f } \\
\text { ठ } \\
\text { ळ }\end{array}$ & 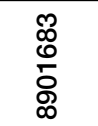 & $\begin{array}{l}\text { స } \\
\text { N } \\
\text { O্ } \\
\infty\end{array}$ & $\begin{array}{l}\text { 옹 } \\
\stackrel{1}{\circ} \\
\infty \\
\varnothing \\
\infty\end{array}$ & $\begin{array}{l}\text { 옹 } \\
\text { 옹 } \\
\text { ᄋ }\end{array}$ & 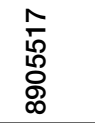 & $\begin{array}{l}\hat{0} \\
\text { న్ } \\
\stackrel{\circ}{\infty}\end{array}$ & $\begin{array}{l}5 \\
\infty \\
\infty \\
\varnothing ్ \\
\varnothing\end{array}$ & $\begin{array}{l}\text { 우 } \\
\text { 이 } \\
\text { ᄋ } \\
\infty\end{array}$ & 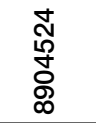 & \multicolumn{2}{|c|}{ 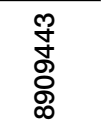 } & 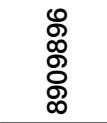 & $\begin{array}{l}\text { : } \\
\text { ठ } \\
\text { : } \\
\text { வ }\end{array}$ \\
\hline $\mathrm{SiO}_{2}$ & 71,29 & 70,33 & 70,25 & 62,14 & 63,15 & 70,69 & 66,91 & 68,29 & 68,94 & 62,29 & 59,26 & \multicolumn{2}{|c|}{72,65} & 64,78 & 56,34 \\
\hline $\mathrm{TiO}_{2}$ & 0,37 & 0,34 & 0,33 & 0,74 & 0,65 & 0,40 & 0,63 & 0,40 & 0,37 & 0,71 & 0,76 & \multicolumn{2}{|c|}{0,07} & 0,79 & 1,16 \\
\hline $\mathrm{Al}_{2} \mathrm{O}_{3}$ & 14,13 & 15,16 & 15,39 & 15,45 & 15,48 & 15,35 & 15,32 & 14,57 & 15,61 & 15,46 & 15,36 & \multicolumn{2}{|c|}{14,80} & 14,12 & 15,40 \\
\hline $\mathrm{Fe}_{2} \mathrm{O}_{3}$ & 2,94 & 1,93 & 1,92 & 5,30 & 4,50 & 2,37 & 3,20 & 3,15 & 1,89 & 5,17 & 5,70 & \multicolumn{2}{|c|}{0,87} & 5,50 & 8,05 \\
\hline $\mathrm{MnO}$ & 0,05 & 0,02 & 0,02 & 0,08 & 0,06 & 0,03 & 0,04 & 0,05 & 0,02 & 0,07 & 0,07 & \multicolumn{2}{|c|}{0,02} & 0,08 & 0,10 \\
\hline $\mathrm{MgO}$ & 1,02 & 0,54 & 0,54 & 2,81 & 2,22 & 0,60 & 1,48 & 1,62 & 0,61 & 2,89 & 3,74 & \multicolumn{2}{|c|}{0,12} & 3,02 & 4,34 \\
\hline $\mathrm{CaO}$ & 1,76 & 1,45 & 1,46 & 3,45 & 4,02 & 1,59 & 2,39 & 3,00 & 1,62 & 4,45 & 4,79 & 0 & 47 & 2,79 & 6,15 \\
\hline $\mathrm{Na}_{2} \mathrm{O}$ & 4,68 & 4,24 & 4,20 & 3,74 & 4,19 & 3,96 & 4,18 & 3,87 & 4,27 & 3,83 & 3,72 & & 72 & 3,65 & 3,73 \\
\hline $\mathrm{K} 2 \mathrm{O}$ & 2,50 & 5,03 & 4,93 & 4,08 & 3,05 & 5,13 & 4,77 & 4,58 & 5,81 & 3,84 & 3,78 & & 11 & 3,43 & 3,00 \\
\hline $\mathrm{P}_{2} \mathrm{O}_{5}$ & 0,11 & 0,11 & 0,10 & 0,24 & 0,23 & 0,05 & 0,45 & 0,20 & 0,16 & 0,41 & 0,37 & & 06 & 0,23 & 0,69 \\
\hline LOI & 1,00 & 0,60 & 0,60 & 1,60 & 2,10 & 0,38 & 0,34 & 0,63 & 0,56 & 0,83 & 1,02 & & 41 & 1,80 & 0,70 \\
\hline Total & 99,85 & 99,75 & 99,74 & $\quad 99,63$ & 99,65 & 100,55 & 99,71 & 100,35 & 99,86 & 99,96 & 98,58 & 99 &, 31 & 100,19 & 99,65 \\
\hline & & cies Ine & quigranu & ular & & & & & Fácies $\mathrm{P}$ & orfirítica & & & & & \\
\hline & $\begin{array}{l}\text { SOS } \\
871 \mathrm{~A}\end{array}$ & $\begin{array}{l}\text { SOS } \\
864\end{array}$ & $\begin{array}{l}\text { SOS } \\
862\end{array}$ & $\begin{array}{c}\text { SOS } \\
866 \\
\end{array}$ & $\begin{array}{l}\text { FDS } \\
495\end{array}$ & $\begin{array}{l}\text { FDS } \\
497\end{array}$ & $\begin{array}{l}\text { SOS } \\
837\end{array}$ & $\begin{array}{l}\text { SOS } \\
840 A\end{array}$ & $\begin{array}{l}\text { SOS } \\
842 A\end{array}$ & $\begin{array}{c}\text { SOS } \\
844\end{array}$ & $\begin{array}{l}\text { SOS } \\
847\end{array}$ & & $\begin{array}{l}\text { OS } \\
3 \mathrm{~A}\end{array}$ & $\begin{array}{l}\text { SOS } \\
861 A\end{array}$ & $\begin{array}{l}\text { SOS } \\
867 A\end{array}$ \\
\hline & 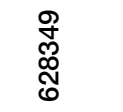 & $\frac{\infty}{\infty}$ & $\begin{array}{l}\text { ஜ్ల్ } \\
\text { ల్ల } \\
\text { ర్ }\end{array}$ & 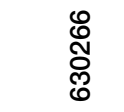 & $\begin{array}{l}\text { ণ } \\
\text { ণ্ } \\
\text { ర్ }\end{array}$ & 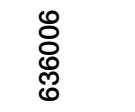 & 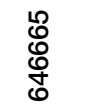 & 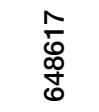 & 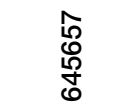 & $\begin{array}{l}\text { లొ } \\
\text { ల్ల } \\
\tilde{\sigma}\end{array}$ & $\frac{\text { న }}{\stackrel{8}{\sigma}}$ & & $\begin{array}{l}\infty \\
0 \\
0 \\
0 \\
0\end{array}$ & $\begin{array}{l}\stackrel{0}{尺} \\
\text { Ðే }\end{array}$ & $\begin{array}{l}\text { ণ } \\
\text { ญิ }\end{array}$ \\
\hline UTM & $\begin{array}{l}\text { 今े } \\
\text { 응 }\end{array}$ & 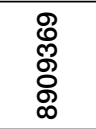 & 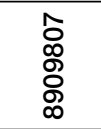 & $\begin{array}{l}\text { ల్ } \\
\text { ᄋ } \\
\text { ळ }\end{array}$ & 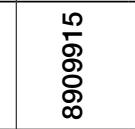 & $\begin{array}{l}\text { 웅 } \\
\frac{\text { क }}{\circ}\end{array}$ & $\begin{array}{l}\text { సิ } \\
\text { ధి } \\
\text { Оి }\end{array}$ & 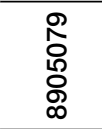 & $\begin{array}{l}0 \\
\text { 옹 } \\
\text { ᄋ } \\
\stackrel{8}{\infty}\end{array}$ & 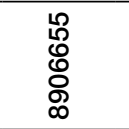 & $\begin{array}{l}0 \\
\infty \\
0 \\
\circ 0 \\
\varnothing \\
\infty\end{array}$ & & 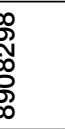 & $\begin{array}{l}\text { సิ } \\
\text { గ్ర } \\
\text { ळ }\end{array}$ & $\frac{\text { న }}{\frac{\Phi}{\infty}}$ \\
\hline $\mathrm{SiO}_{2}$ & 60,72 & 63,35 & 63,95 & 65,06 & 68,42 & 66,92 & 70,15 & 67,94 & 71,99 & 68,53 & 69,74 & 69 &, 42 & 68,4 & 65,32 \\
\hline $\mathrm{TiO}_{2}$ & 0,61 & 0,43 & 0,47 & 0,38 & 0,5 & 0,52 & 0,37 & 0,4 & 0,18 & 0,35 & 0,36 & & 47 & 0,42 & 0,39 \\
\hline $\mathrm{Al}_{2} \mathrm{O}_{3}$ & 14,9 & 15,25 & 15,1 & 14,66 & 14,71 & 15,18 & 14,69 & 15,75 & 14,78 & 14,6 & 14,53 & &, 53 & 14,99 & 14,69 \\
\hline $\mathrm{Fe}_{2} \mathrm{O}_{3}$ & 6,38 & 4,84 & 4,76 & 4,15 & 3,26 & 3,7 & 2,21 & 2,93 & 1,19 & 2,7 & 2,68 & & 59 & 2,81 & 4,05 \\
\hline $\mathrm{MnO}$ & 0,07 & 0,06 & 0,06 & 0,06 & 0,06 & 0,05 & 0,03 & 0,04 & 0,01 & 0,04 & 0,03 & & 06 & 0,04 & 0,06 \\
\hline $\mathrm{MgO}$ & 3,69 & 2,64 & 2,37 & 2,13 & 1,49 & 1,78 & 1,13 & 1,39 & 0,26 & 1,37 & 1,3 & & 46 & 1,3 & 2,09 \\
\hline $\mathrm{CaO}$ & 4,64 & 3,97 & 3,64 & 3,1 & 2,46 & 2,9 & 1,79 & 2,3 & 0,87 & 2,2 & 2,38 & & 55 & 2,79 & 3,37 \\
\hline $\mathrm{Na}_{2} \mathrm{O}$ & 3,41 & 4,01 & 3,98 & 3,84 & 3,93 & 3,88 & 3,89 & 4,06 & 3,7 & 3,9 & 3,7 & & 32 & 4,09 & 3,97 \\
\hline $\mathrm{K} 2 \mathrm{O}$ & 3,93 & 3,45 & 3,65 & 4,64 & 3,9 & 4,03 & 5,22 & 4,84 & 6,71 & 4,7 & 4, & & 17 & 4,51 & 4,0 \\
\hline $\mathrm{P}_{2} \mathrm{O}_{5}$ & 0,34 & 0,31 & 0,34 & 0,29 & 0,19 & 0,2 & 0,23 & 0,32 & 0,08 & 0,21 & 0,2 & & 16 & 0,23 & 0,29 \\
\hline LOI & 0,57 & 0,61 & 2,42 & 0,45 & 0,8 & 0,5 & 0,41 & 0,48 & 0,46 & 0,99 & 0,48 & &, 4 & 0,52 & 0,55 \\
\hline Total & 99,26 & 98,91 & 100,74 & 98,76 & 99,72 & 99,66 & 100,13 & 100,45 & 100,22 & 99,77 & 100,3 & 101 & 1,13 & 100,09 & 98,83 \\
\hline & & & & & & & & & & & & & & & \\
\hline & $\begin{array}{c}\text { SOS } 849 \\
\text { B }\end{array}$ & $\begin{array}{l}\mathrm{SC} \\
85\end{array}$ & & $\begin{array}{l}\text { SOS } \\
853 D\end{array}$ & $\begin{array}{l}\text { SOS } \\
859 B\end{array}$ & $\begin{array}{l}\text { SOS } \\
861 C\end{array}$ & & & $\begin{array}{l}\text { SOS } \\
861 Q\end{array}$ & $\begin{array}{l}\text { SOS } \\
861 P\end{array}$ & & & & & $\begin{array}{l}\text { SOS } \\
876 B\end{array}$ \\
\hline & 639957 & 639 & & 641608 & 635589 & 634708 & 634 & 708 & 634708 & 634708 & 6294 & & & 8349 & 636358 \\
\hline UIM & 8905640 & 8904 & 524 & 3908298 & 8910968 & 8910522 & 8910 & 0522 & 3910522 & 8910522 & 89111 & & 891 & 11047 & 8909699 \\
\hline $\mathrm{SiO}_{2}$ & 55,55 & 48 & & 58,33 & 67,56 & 61,98 & 58 & 19 & 58,72 & 58,72 & 55,0 & & & 6,56 & 53,99 \\
\hline $\mathrm{TiO}_{2}^{2}$ & 1,34 & $1, \subseteq$ & & 1,04 & 0,46 & 0,58 & 0 , & 72 & 0,7 & 0,71 & 0,8 & & &, 61 & 1,29 \\
\hline $\mathrm{Al}_{2} \mathrm{O}_{3}$ & 15,13 & 16 , & & 15,16 & 14,9 & 14,87 & & 01 & 14,85 & 15,08 & 15,0 & & & 3,61 & 15,23 \\
\hline $\mathrm{Fe}_{2} \mathrm{O}_{3}$ & 8,99 & 12, & & 7,27 & 3,34 & 5,87 & 6 & 97 & 6,77 & 6,78 & 8,6 & & &, 55 & 9,74 \\
\hline $\mathrm{MnO}$ & 0,14 & 0, & & 0,11 & 0,05 & 0,09 & 0 & , 1 & 0,1 & 0,1 & 0,12 & & &, 13 & 0,12 \\
\hline $\mathrm{MgO}$ & 4,77 & 5,2 & & 4,02 & 1,63 & 3,07 & 2 & 96 & 3,08 & 3,06 & 4 & & & , 84 & 5,82 \\
\hline $\mathrm{CaO}$ & 6,17 & 8,2 & & 5,25 & 3,09 & 3,69 & 5 & 22 & 4,99 & 4,95 & 6,0 & & & 5,78 & 7,06 \\
\hline $\mathrm{Na}_{2} \mathrm{O}$ & 4,57 & 3,5 & & 4,05 & 3,98 & 3,75 & 3 & 69 & 3,65 & 3,74 & 3,7 & & & ,73 & 3,6 \\
\hline $\mathrm{K}^{2} \mathrm{O}$ & 2,15 & $2, \subseteq$ & & 3,27 & 4,32 & 4,26 & 5 , & 14 & 5,16 & 4,85 & 4,0 & & & 3,69 & 2,28 \\
\hline $\mathrm{P}_{2} \mathrm{O}_{5}$ & 0,37 & $1, \mathrm{C}$ & & 0,62 & 0,24 & 0,44 & 0 , & 74 & 0,71 & 0,71 & 0,7 & & &, 25 & 0,55 \\
\hline LOI & 0,62 & 0,3 & & 0,59 & & 0,57 & 0 & 71 & 0,88 & 0,93 & 0,7 & & &, 93 & 0,77 \\
\hline Total & 99,8 & 100 & & 99,7 & 99,58 & 99,17 & 99 & 45 & 99,62 & 99,62 & 99,7 & & & 0,69 & 100,45 \\
\hline
\end{tabular}

UTM: Universal Transversa de Mercator; LOI: perda ao fogo. 
Na região oeste desse batólito, há abundância de enclaves máficos microgranulares, que eventualmente ocorrem na forma de diques sin-plutônicos (Figura 2F). Os tamanhos e os volumes desses enclaves tendem a diminuir nos afloramentos da parte oeste para a região leste do BRJ. Em contrapartida, percebe-se que há aumento da ocorrência de aglomerados de minerais máficos nesse mesmo sentido. Tobisch et al. (1997) advogam que a presença de diques sin-plutônicos, junto à abundância localizada de enclaves máficos microgranulares em granitos, pode representar o antigo conduto de alimentação do magma máfico. Koyaguchi (1986), ao estudar o Grupo Vulcânico Abu, no Japão, constatou que os aglomerados de minerais máficos sempre se localizam nas porções mais distais dos condutos magmáticos e podem representar a desagregação das gotas dos magmas máficos antes da sua cristalização. Processo similar pode ter ocorrido no BRJ.

A idade de cristalização para o BRJ obtida neste estudo é de $617 \pm 4$ Ma. Essa idade é similar àquela apresentada por Oliveira et al. (2015): $618 \pm 4$ Ma para rochas da região leste do batólito. O BRJ é o maior representante da Suíte Intrusiva Queimada Grande, e a sua forma segue a orientação geral NW-SE dos corpos do DPR, indicando provavelmente controle tectônico regional quando da sua colocação. As estruturas observadas em campo, assim como as texturas ao microscópio das rochas estudadas, não indicam que a colocação desse batólito tenha sido anterior ou sincrônica à estruturação regional. Brito (1996) propõe que a colocação do BRJ tenha sido favorecida pela sutura gerada pela zona de cisalhamento que colocou o DPR em contato com o Domínio Marancó. Corpos intrusivos alongados paralelos à orientação regional e sem deformação importante (e.g., Vigneresse, 1995; Conceição et al., 2003) têm sido preservados da deformação regional, em razão de o seu alojamento ter sido controlado por sistemas tipo pull-apart ou em períodos pós-colisionais.

Alguns autores (e.g., Zen e Hammarstrom, 1984; Ferreira et al., 2011) têm argumentado que o epídoto magmático se cristaliza sob condições de alta fugacidade de oxigênio e à profundidade de $25 \mathrm{~km}$. Brandon et al. (1996) sugerem que a preservação de cristais epídoto magmático em granitos indica alta velocidade de ascensão do magma na crosta. As condições calculadas para a pressão (6,6 kbar) e fugacidade de oxigênio com as composições dos cristais precoces de Mg-hornblenda são similares às relatadas pela bibliografia: 6,6 kbar (geotermômetro $\mathrm{Al}^{\mathrm{T}}$ na hornblenda) e 0,4

Tabela 7. Análises químicas de elementos-traço de rochas do Batólito Rio Jacaré.

\begin{tabular}{|c|c|c|c|c|c|c|c|c|c|c|c|c|c|c|c|c|c|}
\hline \multicolumn{9}{|c|}{ Fácies Inequigranular } & \multicolumn{6}{|c|}{ Fácies Porfirítica } & \multicolumn{3}{|c|}{ Enclaves } \\
\hline & $\begin{array}{c}\text { FDS } \\
492\end{array}$ & $\begin{array}{c}\text { FDS } \\
493\end{array}$ & $\begin{array}{l}\text { SOS } \\
873 A\end{array}$ & $\begin{array}{l}\text { SOS } \\
841\end{array}$ & $\begin{array}{c}\text { FDS } \\
266\end{array}$ & $\begin{array}{c}\text { FDS } \\
265\end{array}$ & 836 & $\begin{array}{l}\text { FDS } \\
261 A\end{array}$ & 497 & $\begin{array}{l}\text { SOS } \\
861 A\end{array}$ & $\begin{array}{l}\text { FDS } \\
495\end{array}$ & $\begin{array}{l}\text { SOS } \\
853 A\end{array}$ & $\begin{array}{c}\text { SOS } \\
837\end{array}$ & $\begin{array}{c}\text { SOS } \\
847\end{array}$ & $\begin{array}{l}\text { SOS } \\
849 B\end{array}$ & $3 \mathrm{D}$ & $\begin{array}{l}\text { SOS } \\
850 B\end{array}$ \\
\hline & 903 & 1231 & & & & & & 522 & & & & & & & 561 & & \\
\hline ib & 140 & 77,1 & & & & & & & & & & & & & & & 8.4 \\
\hline $\mathrm{r}$ & 533 & & & & & & & & & & & & & & & & \\
\hline ir & 215,8 & 6 & & & & & & & & & & & & & & & \\
\hline & & & & & & & & & & & & & & & & & \\
\hline & & & & & & & & & & & & & & & & & 50,4 \\
\hline $\mathrm{Se}$ & & & & & & & & & & & & & & & & & \\
\hline & & & & & & & & & & 10,21 & & & & & & & 14,41 \\
\hline & 34,6 & 8,7 & & & & 32 & & & & 42 & & & & & & & 64,8 \\
\hline m & & & & & & & & & & & & & & & & & 3,1 \\
\hline & & & & & & & & & & & & & & & & & \\
\hline & & & & & & & & & & & & & & & & & \\
\hline & & & & & & & & & & 0,82 & & & & & & & \\
\hline & & & & & & & & & & & & & & & & & \\
\hline $\mathrm{HO}$ & & & 0,7 & & & & & & & 0,72 & & & & & & & 0,82 \\
\hline & & & & & & & & & & & & & & & & & \\
\hline & & & & & & & & & & & & & & & & & 0,24 \\
\hline & & & & & & & & & & & & & & & & & 1,5 \\
\hline & & & & & & & & & & & & & & & & & 0,2 \\
\hline Y & 157 & 12,3 & & & & & & & & 21,94 & & 10,61 & & & 19,84 & & 24,23 \\
\hline & & & & & & & & & & & & & & & 0,44 & & 0,71 \\
\hline & & & & & & & & & & 9,02 & & & & & 6,55 & & 7,96 \\
\hline & 15 & 7,6 & 14,7 & 11,8 & 21,2 & 20,4 & 13,1 & 20,5 & 13,4 & 19,9 & 15,8 & 14 & 12,4 & 18,5 & 4,6 & 8,8 & 8,4 \\
\hline
\end{tabular}


$<\mathrm{Fe} /(\mathrm{Fe}+\mathrm{Mg})<0,5$ (alta fugacidade de oxigênio). O aumento do conteúdo de $\mathrm{Mg}$ e Si e a diminuição do conteúdo de $\mathrm{Al}^{\mathrm{T}}$, observados nos cristais de Mg-hornblenda, devem refletir o reequilíbrio. Evidência de reequilíbrio é igualmente observada nos cristais de biotita e expressa-se pela diminuição do conteúdo de titânio (Figura 7B).

Os conteúdos de $\mathrm{K}_{2} \mathrm{O}$ e $\mathrm{SiO}_{2}$ nas rochas do BRJ revelaram que o batólito tem afinidade com as suítes calcioalcalina de alto $\mathrm{K}$ e os enclaves shoshoníticos. O magmatismo shoshonítico ocorre também a norte, no DPR, no Domínio Canindé e no Terreno Pernambuco Alagoas, e tem idades de cristalização de $617 \pm 23 \mathrm{Ma}$ (Batólito Curituba; Lima, 2016), $613 \pm 7 \mathrm{Ma}$ (Batólito Serra do Catu; Silva Filho et al., 2013) e $611 \pm 4$ Ma (Stock Santa Maria; Soares, 2018).

As tendências evolutivas nos diagramas de Harker, com correlação negativa para $\mathrm{TiO}_{2}, \mathrm{MgO}, \mathrm{CaO}, \mathrm{P}_{2} \mathrm{O}_{3}$ e FeOt (Figura 12), sugerem o fracionamento da titanita, da biotita,

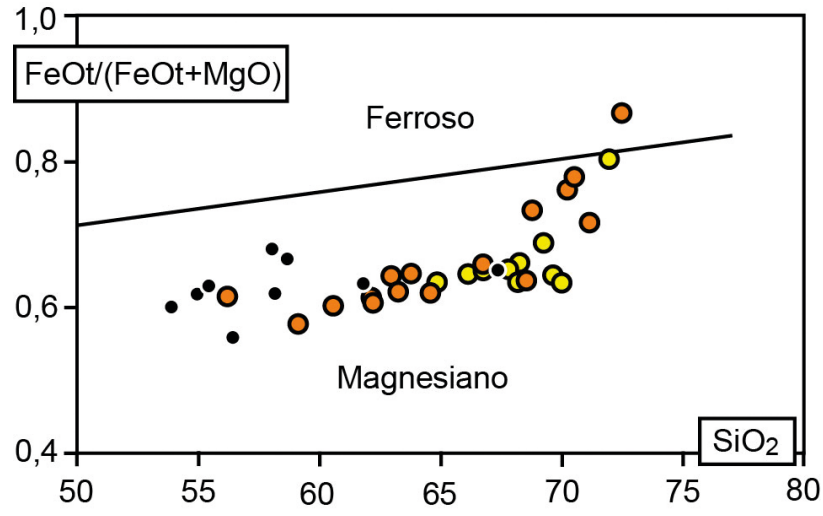

Figura 11. Diagrama $\mathrm{SiO}_{2}$ versus $\mathrm{FeOt} /(\mathrm{FeOt}+\mathrm{MgO})$, de Frost et al. (2001), aplicado às rochas do Batólito Rio Jacaré. Fácies Inequigranular (círculos laranjas); Fácies Porfirítica (círculos amarelos); e enclaves (círculos pretos).
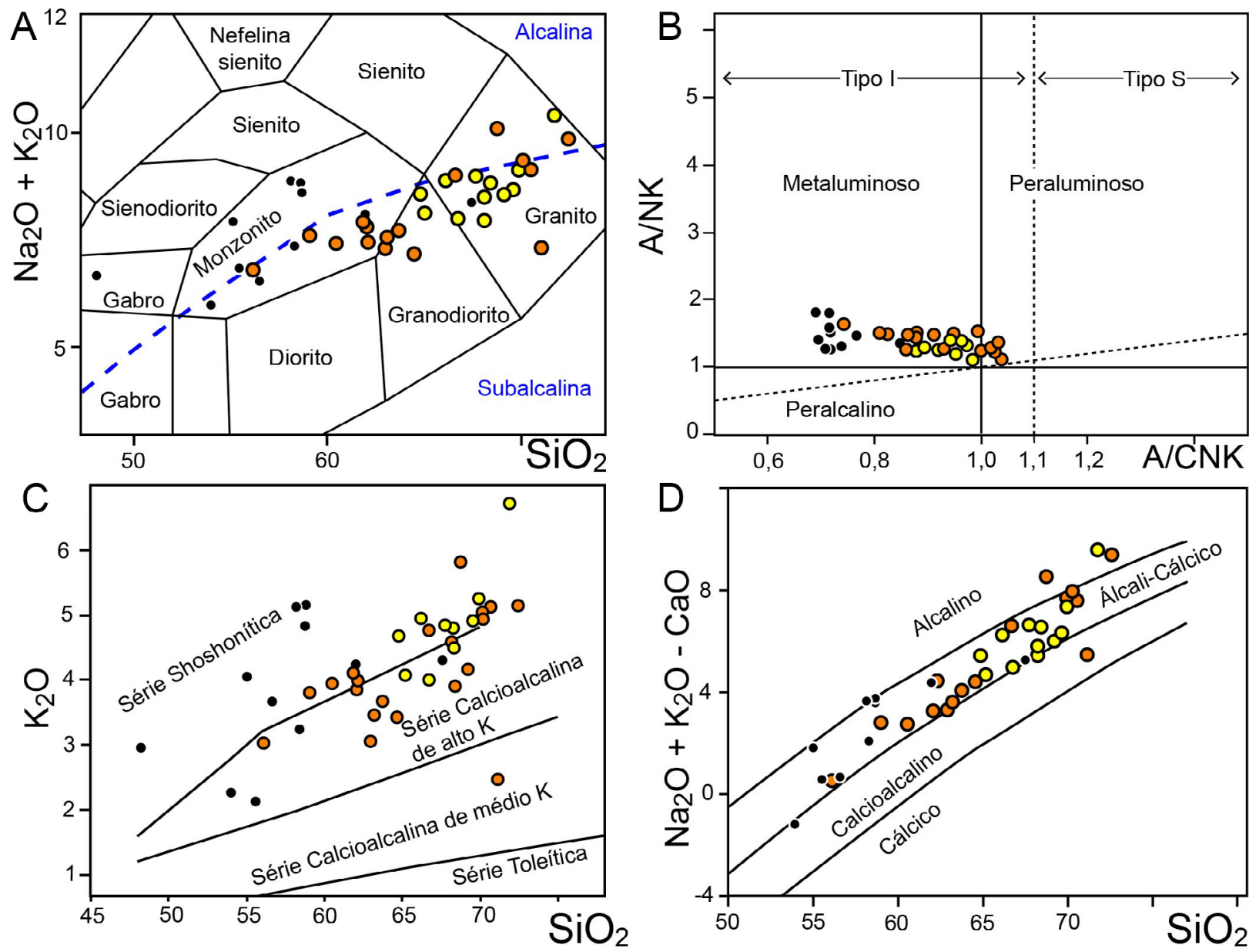

Figura 10. Diagramas geoquímicos aplicados às rochas do Batólito Rio Jacaré: (A) TAS (total de álcalis versus sílica), com campos de Cox et al. (1979); (B) A/NK versus A/CNK (Maniar e Picolli, 1989), com campos dos granitos do Tipo I e S (Chappel e White, 1992); (C) $\mathrm{K}_{2} \mathrm{O}$ versus $\mathrm{SiO}_{2}$ (Peccerillo e Taylor, 1976); (D) $\mathrm{SiO}_{2}$ versus MALI $\left(\mathrm{Na}_{2} \mathrm{O}+\mathrm{K}_{2} \mathrm{O}-\mathrm{CaO}\right.$; Frost et al., 2001). Fácies Inequigranular (círculos laranjas); Fácies Porfirítica (círculos amarelos); enclaves (círculos pretos). 
da hornblenda, da apatita e do plagioclásio no decorrer da diferenciação magmática. Todavia, o caráter retilíneo dessas evoluções negativas $(\mathrm{CaO}, \mathrm{FeOt}$ e $\mathrm{MgO})$ deve refletir a influência do processo de mistura entre magmas na formação das rochas do BRJ. No diagrama MALI de Frost et al. (2001), as rochas do BRJ posicionam nos campos álcali-cálcico, alcalino e calcioalcalino (Figura 10D). Frost e Frost (2008) sugerem que esse comportamento em amostras de um corpo ígneo no diagrama MALI - amostras cruzando os limites dos campos definidos - indica que a cristalização fracionada não foi o único processo atuante durante a evolução. E reflete provavelmente a mistura entre magmas, que pode ser identificada em estruturas de campo e texturas microscópicas.

O enriquecimento dos ETRL em relação aos ETRP indica que houve fracionamento dos ETRP nessas rochas, conforme revelam as razões $(\mathrm{La} / \mathrm{Yb})_{\mathrm{N}}$. Essas variam de 13,56 a 133,09 para as rochas do BRJ e de 6,54 a 22,40 para os enclaves, indicando, assim, que os quartzo monzonitos, monzogranitos e granodioritos do BRJ foram mais fracionados em ETRP que os EMM. Esse enriquecimento pode ser compreendido como resposta ao conteúdo de titanita e apatita modal nas rochas estudadas.

As razões $\left(\mathrm{Eu} / \mathrm{Eu}^{*}\right)$ obtidas para as rochas do BRJ variam entre 0,65 e 0,89 , e dos enclaves, entre 0,68 e 0,97 , e sugerem o fracionamento do plagioclásio na evolução dos magmas.

Os empobrecimentos em $\mathrm{Ti}, \mathrm{Nb}$ e Ta observados no diagrama multielementar são descritos na literatura como uma assinatura geoquímica característica de magmas gerados em ambiente orogênico (e.g., Ringwood, 1990; Foley e Wheller, 1990). As rochas do BRJ apresentam essas características, o que corrobora com os conteúdos de $\mathrm{Y}, \mathrm{Nb}$ e $\mathrm{Rb}$ que alocaram as amostras do BRJ no campo dos granitos formados por magmas gerados em ambientes de arco vulcânico (Figura 14) no diagrama de Pearce et al. (1984). Além disso, esses conteúdos de $\mathrm{Y}, \mathrm{Nb}$ e $\mathrm{Rb}$ são similares àqueles magmas formados em período pós-colisional (Figura 14).

\section{CONCLUSÕES}

O BRJ ocorre em área de $167 \mathrm{~km}^{2}$, tem idade de cristalização $617 \pm 4 \mathrm{Ma}\left(\mathrm{U}-\mathrm{Pb}_{\text {SHIRIMP }}\right.$ em zircão) e é formado de quartzo monzonito, monzogranito e granodiorito magnesianos com afinidade com a série calcioalcalina de alto K. Essas rochas ocorrem em duas fácies petrográficas distintas: Inequigranular e Porfirítica. Em ambas as fácies existem enclaves microgranulares. Esses enclaves têm composições de diorito, quartzo diorito, quartzo monzodiorito, granodiorito e tonalito e possuem afinidade geoquímica com a série shoshonítica.

As formas e os contatos dos enclaves com os granitos encaixantes sugerem a coexistência de magmas no BRJ. Essa hipótese é suportada pela presença de texturas indicativas de mistura entre magmas (e.g., zoneamentos composicionais, zonas de inclusões, cristais de apatita aciculares,
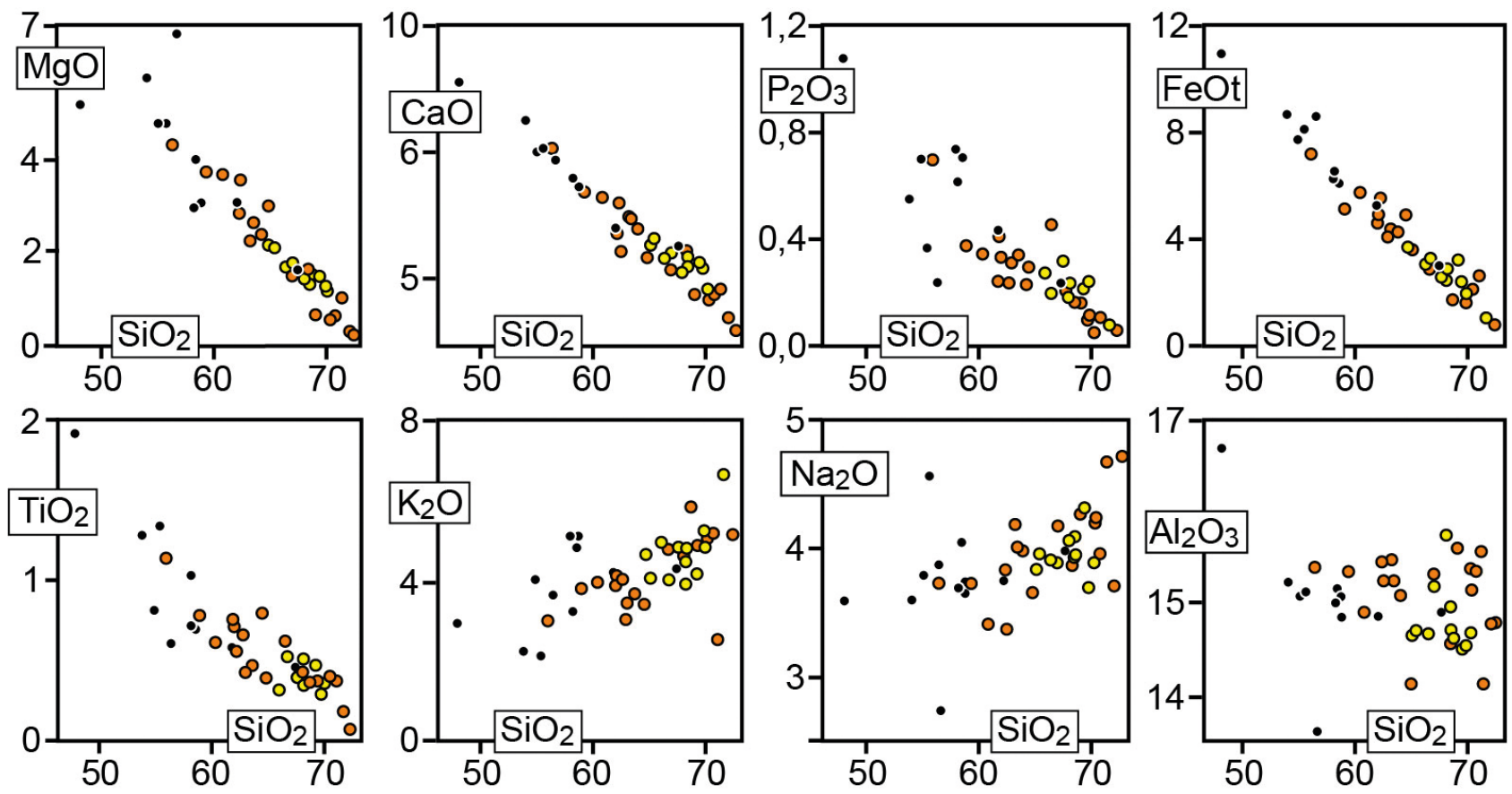

Figura 12. Diagramas binários de variação Harker aplicados a amostras do Batólito Rio Jacaré. Fácies Inequigranular (círculos laranjas); Fácies Porfirítica (círculos amarelos); e enclaves (círculos pretos). 
biotita blade) e pelos trends negativos de FeOt, $\mathrm{CaO}$ e $\mathrm{MgO}$ com formas retilíneas nos diagramas de Harker.

As rochas do BRJ e seus enclaves máficos microgranulares são metaluminosas, magnesianas e têm conteúdo de $\mathrm{SiO}_{2}$ entre 56 e $72 \%$ e de 48 a $67 \%$, respectivamente.

A composição do cristais de plagioclásio das rochas do BRJ varia de oligoclásio a andesina. Os tipos de zonas composicionais presentes no plagioclásio são dominantemente normais, com inversas ocasionais, o que sugere a presença do processo de cristalização fracionada. Esse processo pode ser evidenciado também nos trends negativos de $\mathrm{TiO}_{2}, \mathrm{MgO}$, $\mathrm{CaO}, \mathrm{P}_{2} \mathrm{O}_{3}$ e $\mathrm{FeOt}$ nos diagramas de Harker, indicando o fracionamento de plagioclásio, apatita, titanita, hornblenda e minerais opacos. Essa hipótese é suportada pelas anomalias negativas de Eu e pelo enriquecimento de ETRL em relação aos pesados.
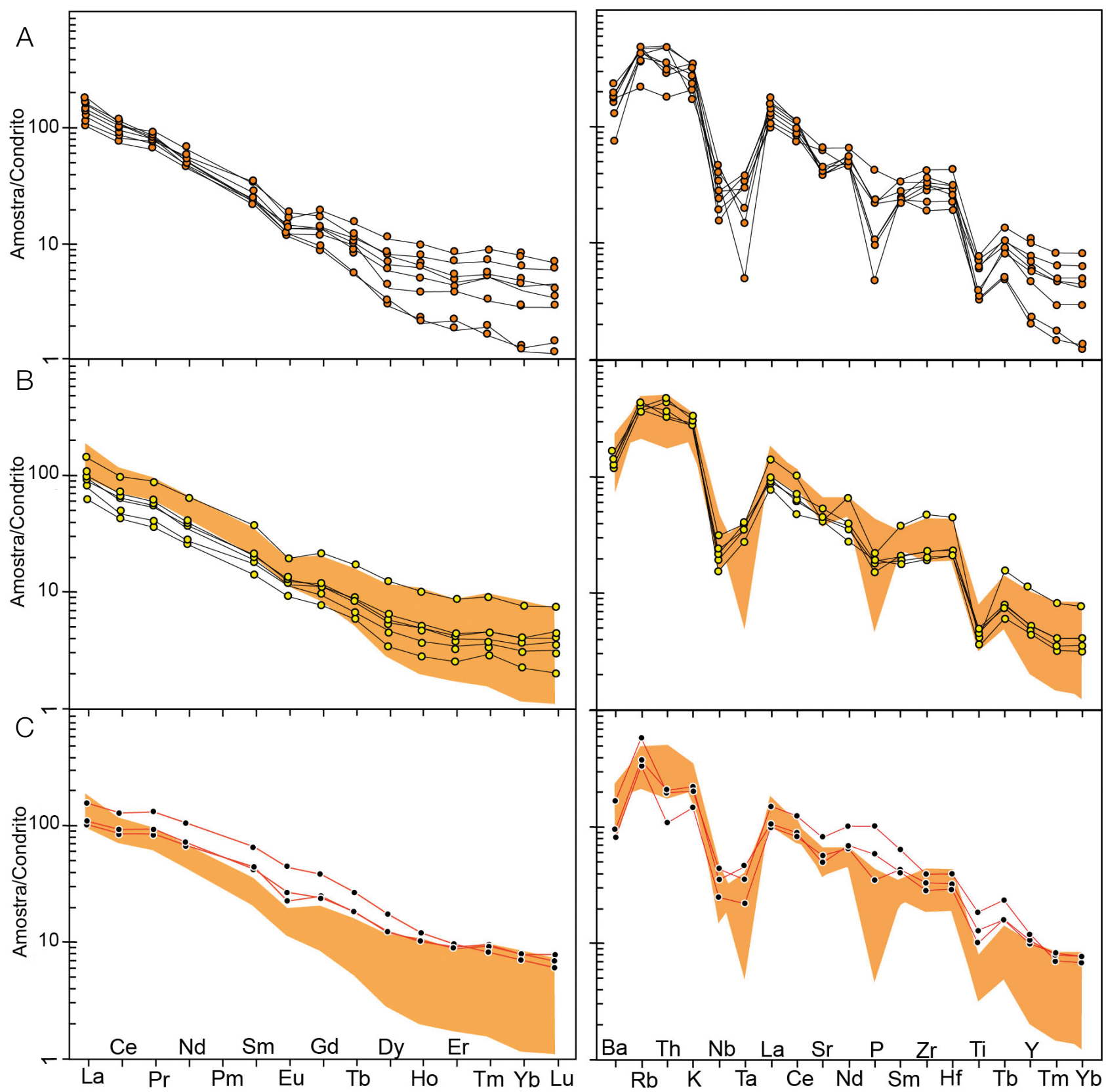

Figura 13. Diagrama elementos terras raras para as rochas do Batólito Rio Jacaré, normalizadas pelo valor do condrito de Nakamura (1974); e diagrama multielementar para as rochas do Batólito Rio Jacaré, normalizadas pelos valores do condrito de Thompson (1982). (A) Fácies Inequigranular; (B) Fácies Porfirítica; (C) enclaves. Área em laranja representa as composições das rochas da Fácies Inequigranular. 
Os dados químicos da biotita apresentam assinatura calcioalcalina do magma do BRJ e evidenciam a presença de reequilíbrio, provavelmente associado ao resfriamento. Com base nas composições da Mg-hornblenda e na presença do epídoto magmático, pode-se inferir que o batólito estudado se cristalizou sob condições de alta fugacidade de oxigênio, pressões em torno de 6,6 Kbar e temperatura de $826^{\circ} \mathrm{C}$.

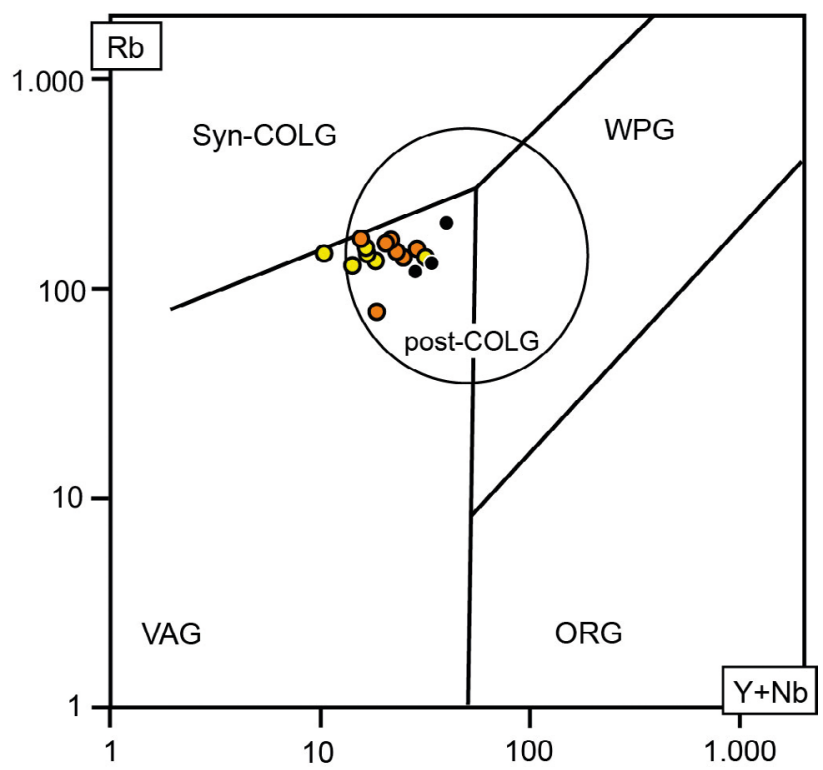

Syn-COLG: granitos sincrônicos à colisão; WPG: granitos intraplaca; VAG: granitos de arcos vulcânicos; ORG: granitos de cordilheira meso-oceânica.

Figura 14. Diagrama $\mathrm{Rb}$ versus $\mathrm{Y}+\mathrm{Nb}$, de Pearce et al. (1984), de discriminação de ambiência tectônica aplicado às rochas do Batólito Rio Jacaré, com campo de granitos pós-colisionais (post-COLG; Pearce, 1996). Fácies Inequigranular (círculos laranjas); Fácies Porfirítica (círculos amarelos); e enclaves (círculos pretos).

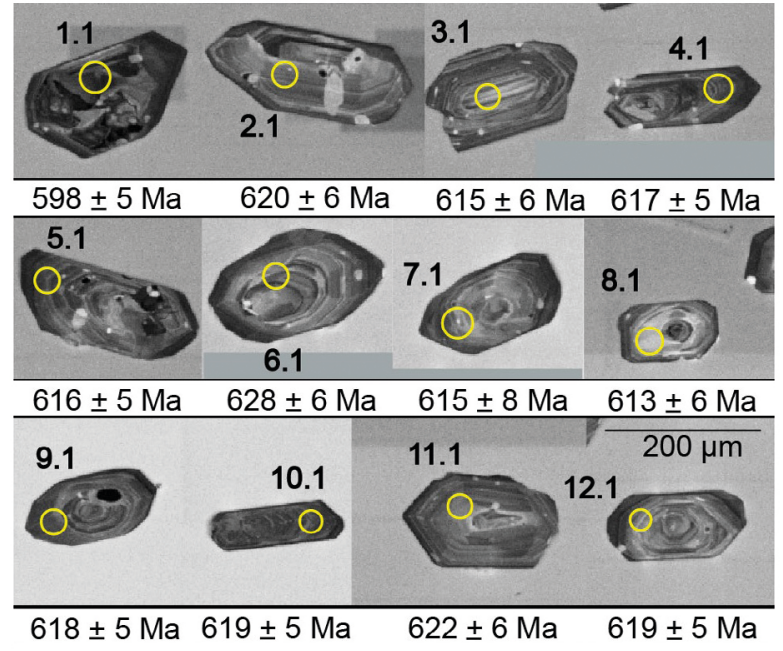

Figura 15. Imagens de catoluminescência dos cristais de zircão analisados (amostra FDS-492 do Batólito Rio Jacaré). Oscírculosrepresentamaposiçãodosspots. Apresentam-se, também, as idades ${ }^{206} \mathrm{~Pb} /{ }^{238} \mathrm{U}$ de cada cristal analisado.

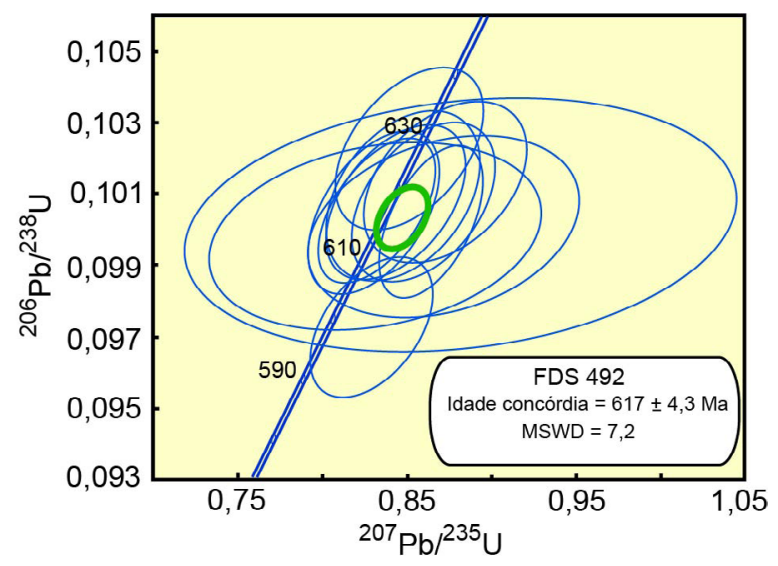

Figura 16. Diagrama concórdia U-Pb para os cristais de zircão da amostra FDS-492 do Batólito Rio Jacaré.

Tabela 8. Dados isotópicos obtidos pelo método U-Pb SHRIMP em cristais de zircão do Batólito Rio Jacaré. Os erros analíticos apresentados são em 2 sigma.

\begin{tabular}{lccc|ccccccc|cc}
\hline \multicolumn{7}{c|}{ Amostra FDS 492 } & \multicolumn{7}{c|}{ Razões isotópicas } & \multicolumn{3}{c}{ Idades (Ma) } \\
\hline Spot & $\begin{array}{c}\mathbf{U} \\
\text { (ppm) }\end{array}$ & $\begin{array}{c}\text { Th } \\
\text { (ppm) }\end{array}$ & Th/U & ${ }^{206} \mathrm{~Pb} /{ }^{204} \mathrm{~Pb}$ & ${ }^{207} \mathrm{~Pb} /{ }^{206} \mathrm{~Pb}$ & $\pm \%$ & ${ }^{208} \mathrm{~Pb} /{ }^{206} \mathrm{~Pb}$ & $\pm \%$ & ${ }^{206} \mathrm{~Pb} /{ }^{238} \mathrm{U}$ & $\pm \%$ & ${ }^{206} \mathrm{~Pb} /{ }^{238} \mathrm{U}$ & Disc (\%) \\
\hline 1.1 & 964 & 309 & 0,33 & 17,76 & 0,0694 & 0,6 & 0,128 & 2,4 & 0,0973 & 0,83 & $598 \pm 5$ & 11 \\
2.1 & 318 & 284 & 0,92 & 17,72 & 0,0659 & 1,0 & 0,294 & 1,1 & 0,1010 & 0,95 & $620 \pm 6$ & 2 \\
3.1 & 201 & 171 & 0,88 & 17,73 & 0,0683 & 2,6 & 0,273 & 1,5 & 0,1001 & 1,04 & $615 \pm 6$ & 14 \\
4.1 & 414 & 238 & 0,59 & 17,73 & 0,0637 & 0,9 & 0,183 & 1,2 & 0,1004 & 0,90 & $617 \pm 5$ & -3 \\
5.1 & 457 & 287 & 0,65 & 17,73 & 0,0643 & 0,8 & 0,208 & 1,1 & 0,1002 & 0,88 & $616 \pm 5$ & 12 \\
6.1 & 349 & 229 & 0,68 & 17,71 & 0,0646 & 0,9 & 0,213 & 2,3 & 0,1023 & 0,93 & $628 \pm 6$ & -1 \\
7.1 & 252 & 156 & 0,64 & 17,73 & 0,0899 & 3,9 & 0,274 & 1,3 & 0,1001 & 1,43 & $615 \pm 8$ & 17 \\
8.1 & 176 & 125 & 0,73 & 17,73 & 0,0686 & 3,1 & 0,245 & 4,6 & 0,0998 & 1,07 & $613 \pm 6$ & 1 \\
9.1 & 423 & 314 & 0,77 & 17,72 & 0,0630 & 0,8 & 0,234 & 1,0 & 0,1006 & 0,89 & $618 \pm 5$ & -3 \\
10.1 & 418 & 226 & 0,56 & 17.72 & 0,0648 & 0,9 & 0,178 & 1,3 & 0,1008 & 0,90 & $619 \pm 5$ & 2 \\
11.1 & 359 & 225 & 0,65 & 17,72 & 0,0637 & 1,8 & 0,198 & 2,4 & 0,1013 & 0,93 & $622 \pm 6$ & 10 \\
12.1 & 437 & 228 & 0,54 & 17,72 & 0,0662 & 0,9 & 0,184 & 1,3 & 0,1008 & 0,91 & $619 \pm 5$ & 8 \\
\hline
\end{tabular}


Os elementos-traço $\mathrm{Ta}$, $\mathrm{Nb}$ e Ti exibem baixos valores, que sugerem uma ambiência orogênica do magma Rio Jacaré, enquanto conteúdos de $\mathrm{Y}, \mathrm{Nb}$ e $\mathrm{Rb}$ indicam similaridade com magmas posicionados em fase pós-colisional.

\section{AGRADECIMENTOS}

O presente trabalho foi realizado com o apoio da Coordenação de Aperfeiçoamento de Pessoal de Nível Superior (CAPES) 001. Os autores Carlos Santana Sousa e Hiakan Santos Soares agradecem à CAPES suas bolsas de mestrado. Os autores expressam igualmente agradecimento ao Conselho Nacional de Desenvolvimento Científico e Tecnológico (CNPq) o suporte financeiro para alcançar os objetivos do trabalho (processos $n^{\circ} 384713 / 2015-7,405387 / 2016-4$, $310391 / 2017-2$ e 311008/2017-8). Este trabalho é parte da dissertação de mestrado do primeiro autor, que foi realizado no Laboratório de Petrologia Aplicada à Pesquisa Mineral da Universidade Federal de Sergipe (LAPA-UFS). Aos professores Adejardo Francisco da Silva Filho (Universidade Federal de Pernambuco - UFPE), Adriane Machado (UFS), Luiz Alberto Vedana (UFS) e Simone Cerqueira Pereira Cruz (Universidade Federal da Bahia — UFBA), expressamos nossos agradecimentos as críticas e as sugestões que enriqueceram o trabalho. Agradecemos igualmente as sugestões dos dois avaliadores anônimos da Revista Geologia USP. Série Cientifica.

\section{REFERÊNCIAS}

Abdel-Rahman, A. (1994). Nature of biotites from alkaline, calc-alkaline, and peraluminous magmas. Journal of Petrology, 35(2), 525-541. https://doi.org/10.1093/ petrology/35.2.525

Almeida, F., Hasuí, Y., Brito Neves, B., Fuck, R. (1977). Províncias estruturais brasileiras. VIII Simpósio de Geologia do Nordeste, 363-391. Campina Grande: SBG.

Anderson, J., Smith, D. (1995). The effects of temperature and $\mathrm{fO}_{2}$ on the Al-in hornblende barometer. American Mineralogist, 80(5-6), 549-559. https://doi.org/10.2138/ am-1995-5-614

Bates, R., Jackson, J. (1980). Glossary of geology. $2^{\mathrm{a}} \mathrm{ed}$. Portland: American Geological Institute.

Bonin, B. (2004). Do coeval mafic and felsic magmas in post-collisional to within-plate regimes necessarily imply two contrasting, mantle and crustal, sources? A review. Lithos, 78(1-2), 1-24. https://doi.org/10.1016/j.lithos.2004.04.042

Brandon, A., Creaser, R., Chacko, T. (1996). Constrains on rates of granitic magma transport from epidote dissolution kinetics. Science, 271(5257), 1845-1848. https://doi. org/10.1126/science.271.5257.1845

Brito, M. F. L. (1996). Geologia, geoquimica e petrologia do Complexo Granitico Sítios Novos, Sistema de Dobramentos Sergipano. Dissertação (Mestrado). Recife: Universidade Federal de Pernambuco.

Bueno, J., Oliveira, E., McNaughton, N., Laux, J. (2009). U-Pb dating of granites in the Neoproterozoic Sergipano Belt, NE-Brazil: Implications for the timing and duration of continental collision and extrusion tectonics in the Borborema Province. Gondwana Research, 15(1), 86-97.https://doi.org/10.1016/j.gr.2008.06.003

Carvalho, J. M. (2005). Evolução tectônica do Domínio Poço Redondo-Marancó: registro das orogêneses Cariris Velhos e Brasiliana na Faixa Sergipana, NE do Brasil. Tese (Doutorado). Campinas: Universidade de Campinas.

Chappell, B., White, J. (1992). I- and S-type granites in the Lachlan Fold Belt. In: B. Chappell, J. White (Eds.). Transation of Royal Society Edinburg: Earth Sciences, 83(1-2), 1-26. Estados Unidos: Geological Society of America. https://doi.org/10.1130/SPE272-p1

Conceição, H., Rosa, M. L. S., Macambira, M. J. B., Scheller, T., Marinho, M. M., Rios, D. C. (2003). 2.09 Ga idade mínima da cristalização do Batólito Sienítico Itiúba: um problema para o posicionamento do clímax do metamorfismo granulítico (2,05-2,08 Ga) no Cinturão Móvel Salvador-Curaçá, Bahia? Revista Brasileira de Geociências, 33(4), 395-398. https:// doi.org/10.25249/0375-7536.2003334395398

Conceição, J., Rosa, M. L. S., Conceição, H. (2016). Sienogranitos leucocráticos do Domínio Macururé, Sistema Orogênico Sergipano, Nordeste do Brasil: Stock Glória Sul. Brazilian Journal of Geology, 46(1), 63-77. https://doi. org/10.1590/2317-4889201620150044

Cox, K. G., Bell, J. D., Panknurst, R. J. (1979). The interpretation of igneous rocks. Londres: George Allen \& Unwin. https://doi.org/10.1007/978-94-017-3373-1

Davison, I., Santos, R. (1989). Tectonic Evolution of the Sergipano Fold Belt, NE Brazil, during the Brasiliano Orogeny. Precambrian Research, 45(4), 319-342. https:// doi.org/10.1016/0301-9268(89)90068-5 
Deer, W., Howie, R., Zussman, J. (1992). Rock-forming minerals. $2^{\mathrm{a}}$ ed. Londres: Longman.

Elkins, L., Grove, T. (1990). Ternary feldspar experiments and thermodynamic models. American Mineralogist, 75(5-6), 544-559.

Ferreira, V., Sial, A., Pimentel, M., Armstrong, R., Spicuzza, M., Guimarães, I., Silva Filho, A. (2011). Contrasting source and P-T crystalization condictions of epidote-bearing granitic rocks, northeastern Brazil: O, Sr, and Nd isotopes. Lithos, 121(1-4), 189-201. https://doi.org/10.1016/j.lithos.2010.11.002

Foley, S., Wheller, G. (1990). Parallels in the origin of the geochemical signatures of island arc volcanic and continental potassic igneous rocks. Chemistry Geology, 85(1-2), 1-18. https://doi.org/10.1016/0009-2541(90)90120-V

Frost, B., Barnes, C., Collins, W., Arculus, R., Ellis, D., Frost, C. (2001). A geochemical classification for granitic rocks. Journal of Petrology, 42(11), 2033-2048. https://doi. org/10.1093/petrology/42.11.2033

Frost, B., Frost, C. (2008). A geochemical classification for Feldspathic Igneous Rocks. Journal of Petrology, 49(11), 1955-1969. https://doi.org/10.1093/petrology/egn054

Fuhrman, M., Lindslay, D. (1988). Ternary-feldspar modeling and thermometry. American Mineralogist, 73(3-4), 201-215.

Fujimori, S. (1989). Contribuição ao estudo dos granitoides do Sistema de Dobramentos Sergipano. Revista Brasileira de Geociências, 19(2), 241-247. https://doi. org/10.25249/0375-7536.1989241247

Gaston, G., Santos, R. (1988). Geoquímica de alguns granitóides do Sistema de Dobramentos Sergipana. $X X X V$ Congresso Brasileiro de Geologia, 3, 1037-1052. Belém: SBG.

Gentil, T. (2013). Petrologia e Geoquímica do Batólito Shoshonítico Serra do Brejo no Domínio Poço Redondo, Faixa Sergipana (Sul da Província Borborema). Dissertação (Mestrado). São Cristóvão: Universidade Federal de Sergipe.

Gouveia, G. (2016). Contribuição à petrografia e geoquímica do Stock Umbuzeiro do Matuto, Sistema Orogênico Sergipano. Monografia (Graduação). São Cristóvão: Universidade Federal de Sergipe.

Guimarães, I., Silva Filho, A. (1995). An example of in situ granite formation in the northern boundary of the Proterozoic Sergipano fold beld, NE Brazil: the Xingó Complex. Journal of South American Earth Sciences, 8(3-4), 341-354. https:// doi.org/10.1016/0895-9811(95)00018-B
Hibbard, M. (1991). Textural anatomy of twelve magmamixed granitoid systems. In: J. Didier, B. Barbarin (Eds.). Enclaves and granite petrology, 431-444. Amsterdam: Elsevier Science. (Developments in Petrology, 13).

Holland, T. J., Blundy, J. D. (1994). Non-ideal interactions in calcic amphiboles and their bearing on amphiboleplagioclase thermometry. Contributions to Mineralogy and Petrology, 116(4), 433-477. https://doi.org/10.1007/ BF00310910

Kirkland, C., Smithies, R., Taylor, R., Evans, N., McDonald, B. (2015). Zircon $\mathrm{Th} / \mathrm{U}$ ratios in magmatic environs. Lithos, 212-215, 397-414. https://doi.org/10.1016/j. lithos.2014.11.021

Koyaguchi, T. (1986). Textural and compositional evidence for magma mixing and its mechanism, Abu volcano group, Southwestern Japan. Contributions to Mineralogy and Petrology, 93(1), 33-45. https://doi.org/10.1007/ BF00963583

Le Maître, R., Bateman, P., Dudek, A., Keller, J., Lameyre, M., Le Bas, M. J., Sabine, P. A., Shimid, R., Sorensen, H., Streckeisen, A., Wolley, R., Zanettin, B. (1989). A classification of igneous rocks and glossary of terms. Oxford: Blackwell Scientific Publications.

Leake, B., Woolley, A., Arps, C., Birch, W., Gilbert, M., Grice, J., Hawthorne, F. C., Kato, A., Kisch, H. J., Krivovichev, V. G., Linthout, K., Laird, J., Mandarino, J. A., Maresch, W. V., Nickel, E. H., Rock, N. M. S., Schumacher, J. C., Smith, D. C., Stephenson, N. C. N., Ungaretti, L., Whittaker, E. J. W., Youzhi, G. (1997). Nomenclature of amphiboles: Report of the subcommittee on amphiboles of the International Mineralogical Association, commission on new minerals and mineral names. American Mineral, 9(3), 623-651. https:// doi.org/10.1127/ejm/9/3/0623

Lima, D. (2016). Caracterização petrológica e geoquímica do Pluton Curituba, Domínio Poço Redondo-Marancó, Cinturão Sergipano. Dissertação (Mestrado). Recife: Universidade Federal de Pernambuco.

Lima, R., Rosa, M., Conceição, H. (2017). Petrografia e química mineral do Batólito Serra Negra, Domínio Poço Redondo, Sistema Orogênico Sergipano. XXVII Simpósio de Geologia do Nordeste. João Pessoa: SBG.

Maniar, P. D., Picolli, P. M. (1989). Tectonic discrimination of granitoids. Geological Society of American Bulletin, 101(5), 635643. https://doi.org/10.1130/0016-7606(1989)101<0635:TDO $\mathrm{G}>2.3 . \mathrm{CO} ; 2$ 
McReath, I., Lafon, J., Davison, I., Chaves, J., Conceição, H. (1998). Brasiliano-age granitoids in the Sergipana Fold Belt, NE Brazil: the Coronel João Sá Pluton. Journal of South American Earth Sciences, 11(1), 51-66. https://doi. org/10.1016/S0895-9811(97)00036-9

Morrison, G. (1980). Characteristics and tectonic setting of the shoshonite rock association. Lithos, 13(1), 97-108. https://doi.org/10.1016/0024-4937(80)90067-5

Nachit, H., Ibhi, A., Abia, E., Ohoud, M. (2005). Discrimination between primary magmatic biotites, reequilibrated and neoformed biotites. Comptes Rendus Geoscience, 337(16), 1415-1420. https://doi.org/10.1016/j.crte.2005.09.002

Nakamura, N. (1974). Determination of REE, Ba, Fe, $\mathrm{Mg}, \mathrm{Na}$ and $\mathrm{K}$ in carbonaceous and ordinary chondrites. Geochemica et Cosmochimica Acta, 38(5), 757-775. https:// doi.org/10.1016/0016-7037(74)90149-5

Oliveira, E. P., Bueno, J., McNaughton, N., Silva Filho, A., Nascimento, R., Donatti-Filho, J. (2015). Age, composition and source of continental arc- and syncollision granites of the Neoproterozoic Sergipano Belt, Southern Borborema Province, Brazil. Journal of South American Earth Sciences, 58, 257-280. https://doi. org/10.1016/j.jsames.2014.08.003

Oliveira, E. P., Windley, B., Araújo, M. (2010). The Neoproterozoic Sergipano orogenic belt, NE Brazil: A complete plate tectonic cycle in western Gondwana. Precambrian Research, 181(1-4), 64-84. https://doi. org/10.1016/j.precamres.2010.05.014

Pearce, J. A. (1996). Source and settings of granites rocks. Episodes, 19(4), 120-125.

Pearce, J. A., Harris, N. B., Tindle, A. G. (1984). Trace element discrimination diagrams for the tectonic interpretation of granitic rocks. Journal of Petrology, 25(4), 956-983. https:// doi.org/10.1093/petrology/25.4.956

Peccerillo, A., Taylor, S. R. (1976). Geochemistry of Eocene Calc-Alkaline Volcanic Rocks from the Kastamonu Area, Northen Turkey. Contribution Mineralogy Petrology, 58(1), 63-81. https://doi.org/10.1007/BF00384745

Perugini, D., Poli, G. (2011). Intrusion of mafic magmas into felsic magma chambers: new insights from natural outcrops and fluid-mechanics experiments. Italian Journal of Geosciences, 130(1), 3-15. https://doi.org/10.3301/ IJG.2010.22
Pinho Neto, M. A., Sousa, C. S., Oliveira, D. B., Rosa, M. L. S., Conceição, H. (2017). Feições Petrográficas e Geoquímicas do Batólito Sítios Novos, Domínio Poço Redondo, Sistema Orogênico Sergipano. XXVII Simpósio de Geologia do Nordeste. João Pessoa: SBG.

Pupin, J. (1980). Zircon and Granite Petrology. Contributions to Mineralogy and Petrology, 73(3), 207-220. https://doi. org/10.1007/BF00381441

Ringwood, A. (1990). Slab-mantle interaction Petrogenesis of intraplate magmas and structure of the upper mantle. Chemical Geology, 82, 187-207. https://doi. org/10.1016/0009-2541(90)90081-H

Santos, R., Martins, A., Neves, J., Leal, R. (2001). Programa Levantamentos Geológicos Básicos do Brasil - PLGB. Geologia e recursos minerais do Estado de Sergipe. Escala 1:250.000. Texto explicativo do Mapa Geológico do Estado de Sergipe. Brasília: CPRM/DIEDIG/ DEPAT, CODISE.

Santos, R., Souza, J. (1988). Programa Levantamentos Geológicos Básicos do Brasil - Piranhas Folha SC.24X-C-VI - Estados de Sergipe, Alagoas e Bahia. Brasília: DNPM/CPRM.

Sato, K., Tassinari, C., Basei, M., Siga Júnior, O., Onoe, A., Souza, M. (2014). Sensitive High Resolution Ion Microprobe (SHRIMP IIe/MC) of the Institute of Geosciences of the University of São Paulo, Brazil: analytical method and first results. Geologia USP. Série Cientifica, 14(3), 3-18. https://doi.org/10.5327/ Z1519-874X201400030001

Silva Filho, A. F., Guimarães, I. P., Van Schmus, W. R., Dantas, E., Armstrong, R., Concentino, L., Lima, D. (2013). Longlived Neoproterozoic high-K magmatism in the PernambucoAlagoas Domain, Borborema Province, northeast Brazil. International Geology Review, 55(10), 1280-1299. https:// doi.org/10.1080/00206814.2013.774156

Silva Filho, M., Torres, H. (2002). A new interpretation on the Sergipano Belt domains. Anais da Academia Brasileira de Ciências, 74(3), 556-557. https://doi.org/10.1590/ S0001-37652002000300049

Soares, H. S. (2018). Petrografia, química mineral e geoquímica dos stocks Santa Maria, Monte Pedral, Bom Jardim, Boa Esperança e Niterói, Suite Intrusiva Serra Do Catu, Sergipe. Dissertação (Mestrado). São Cristóvão: Universidade Federal de Sergipe. 
Sousa, C. S., Soares, H. S., Pinho Neto, M. A., Oliveira, D. B., Rosa, M. L. S., Conceição, H. (2017). Batólito Bela Vista, Sistema Orogênico Sergipano, Nordeste do Brasil: Geologia, Petrografia, Geoquímica e Química Mineral. XXVII Simpósio de Geologia do Nordeste. João Pessoa: SBG.

Streckeisen, A. (1976). To each plutonic rock its proper name. Earth Science Reviews, 12(1), 121-133. https://doi. org/10.1016/0012-8252(76)90052-0

Teixeira, L., Lima, E., Neves, J., Santos, R., Santiago, R., Melo, R. (2014). Mapa Geológico e de Recursos Minerais do Estado de Sergipe. Escala 1:250.000. Brasil: CPRM.

Thompson, R. (1982). Magmatism of the British Tertiary Volcanic Province. Scottish Journal of Geology, 18(1), 50-107. https://doi.org/10.1144/sjg18010049

Tobisch, O., McNulty, B., Vernon, R. (1997). Microgranitoid enclave swarms in granitic plutons, central Sierra Nevada, California. Lithos, 40(2-4), 321-339. https://doi.org/10.1016/ S0024-4937(97)00004-2

Tulloch, A. (1979). Secondary Ca-Al silicates as low-grade alteration products of granitoid biotite. Contributions to Mineralogy and Petrology, 69(2), 105-117. https://doi. org/10.1007/BF00371854

Tulloch, A. (1986). Comments and reply on "Implecations of magmatic epidote-bearing plutons on crustal evolution in the accreted terranes of nothwestern North America" and "Magmatic epidote and its petrologic significance". Geology, 14(2), 186187. https://doi.org/10.1130/0091-7613(1986)14<186:CAR $\mathrm{OIO}>2.0 . \mathrm{CO} ; 2$
Vernon, R., Etheridge, M., Wall, V. (1988). Shape and microstructure of microgranitoid enclaves: indicators of magma mingling and flow. Lithos, 22(1), 1-11. https://doi. org/10.1016/0024-4937(88)90024-2

Vigneresse, J. L. (1995). Control of granite emplacement by regional deformation. Tectonophysics, 249(3-4), 173-186. https://doi.org/10.1016/0040-1951(95)00004-7

Weidendorfer, D., Mattsson, H., Ulmer, P. (2014). Dynamics of magma mixing in partially crystallized magma chambers: textural and petrological constraints from the basal Complex of the Austurhorn Intrusion (SE Iceland). Journal of Petrology, 55(9), 1865-1903. https://doi.org/10.1093/petrology/egu044

Zanetti, A., Mazzucchelli, M., Rivalenti, G., Vannucci, R. (1999). The Finero phlogopite-peridotite massif: an example of subduction-related metasomatism. Contribution to Mineralogy and Petrology, 134(2-3), 107-122. https://doi. org/10.1007/s004100050472

Zen, E., Hammarstrom, J. (1984). Magmatic epidote and its petrologic significance. Geological Society of American, 12(9), 515-518. https://doi. org/10.1130/0091-7613(1984)12<515:MEAIPS $>2.0 . C O ; 2$

Zheng, J., Griffin, W., O'Reilly, S., Yang, J., Li, T., Zhang, M., Zhang, R., Liou, J. (2006). Mineral chemistry of peridotites from Paleozoic, Mesozoic and Cenozoic lithosphere: constraints on mantle evolution beneath eastern China. Journal of Petrology, 47(11), 2233-2256. https://doi.org/10.1093/petrology/egl042

Zhou, Z. (1986). The origin of intrusive mass in Fengshandong, Hubei province. Acta Petrologica Sinica, 2(2), 59-70. 